\title{
A EFICÁCIA DA LEI MARIA DA PENHA NO COMBATE À VIOLÊNCIA DOMÉSTICA CONTRA A MULHER: \\ ALGUMAS REFERÊNCIAS NO DISTRITO FEDERAL
}

DENISE MENDES NOGUEIRA

BRASILIA

2008 
DENISE MENDES NOGUEIRA

\section{A EFICÁCIA DA LEI MARIA DA PENHA NO COMBATE À VIOLÊNCIA DOMÉSTICA CONTRA A MULHER:}

ALGUMAS REFERÊNCIAS NO DISTRITO FEDERAL

Trabalho a ser apresentado como requisito parcial de avaliação na disciplina Trabalho de Conclusão de Curso de Serviço Social da Universidade de Brasília, sob orientação da professora Neuza Farias de Araújo.

BRASILIA

2008 
Dedicatória:

À minha mãe pelo incentivo e apoio, meu eterno agradecimento. 
Agradecimentos:

Agradeço a Deus por abençoar meu caminho e a professora Neuza Farias de Araújo pela ajuda.

"Todas as mágoas são suportáveis quando fazemos delas uma história ou contamos uma história a seu respeito." Isak Dinesen. 


\section{SUMÁRIO}

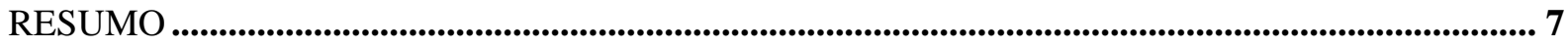

INTRODUÇÃO ............................................................................................................................................................... 8

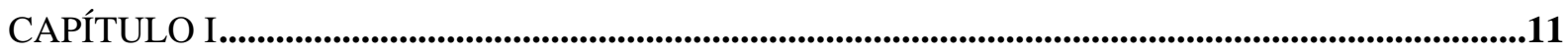

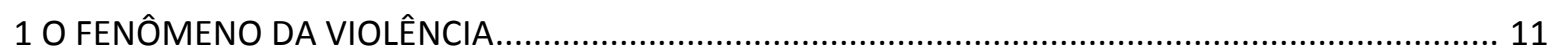

1.1A violência contra a mulher dentro e fora do ambiente doméstico..................................... .13

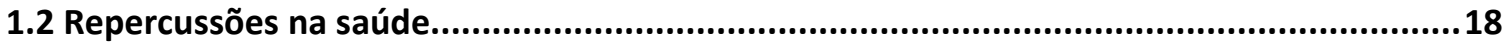

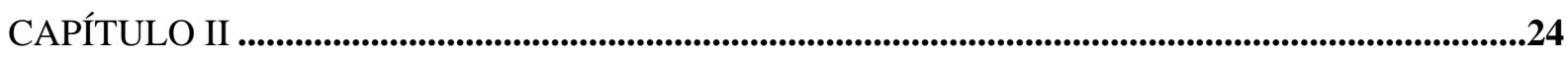

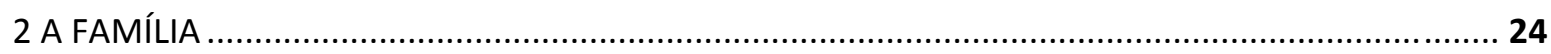

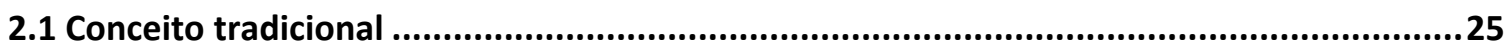

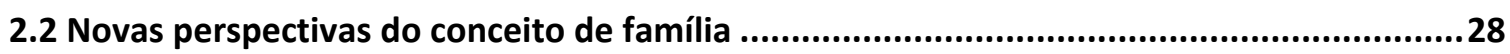

2.3 Mudanças na relação familiar: mulher nas transformações sociais............................ . . . 30

CAPÍTULO III ..............................................................................................................................................36

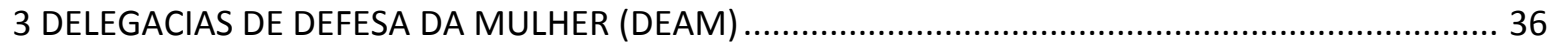

3.10 sistema jurídico brasileiro de combate à violência doméstica.........................................42

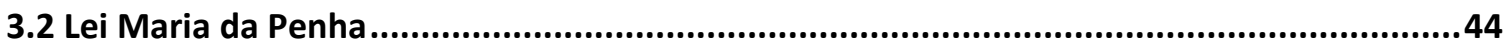

3.3 A experiência da Casa Abrigo...........................................................................................50

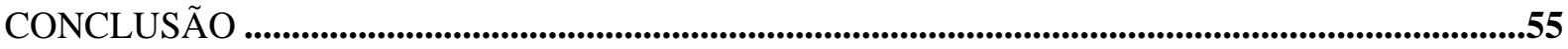

REFEREANCIAS ..........................................................................................................................................................59

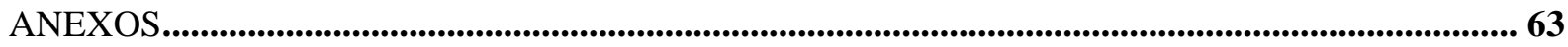




\section{LISTA DE ABREVIATURAS E SIGLAS}

PAISM - Programa de Atenção Integral à Saúde da Mulher

PAVI - Programa de Violência

HRAN - Hospital Regional da Asa Norte

DEAM - Delegacia Especial de Atendimento à Mulher 


\section{RESUMO}

As mulheres são vítimas históricas do preconceito baseado no gênero, ocupando espaços inferiores aos dos homens dentro da sociedade. O fato é que, durante anos a sociedade ignorou tal subjugação dentro do próprio lar dessas mulheres. Vítimas de seus próprios companheiros, elas permaneceram em total silêncio por medo de serem desamparadas pelo Estado e pela sociedade. Em meio a lutas e reivindicações do movimento feminista o fenômeno da violência doméstica gradualmente vem ganhando repercussão e culminou com a edição da Lei Maria da Penha, a qual garante diversos mecanismos para amparar as vítimas e possibilitar que elas vivam dignamente.

No presente trabalho, pretende-se responder à seguinte pergunta: Em que medida a Lei Maria da Penha contribuiu para o aumento das denúncias por parte das mulheres vítimas de violência doméstica?

O que podemos afirmar com precisão é que a nova Lei apresenta-se como um mecanismo eficaz no combate à violência doméstica, mas tomando como base o seu próprio texto, pesquisas bibliográficas e três instituições voltadas para o combate a este crime, é possível dizer que tal instrumento normativo influenciará no aumento das denúncias desde que haja um trabalho voltado para sua divulgação para toda a comunidade.

Palavras-chave: violência contra a mulher. violência doméstica. violência de gênero. família. movimento feminista. 


\section{INTRODUÇÃO}

O presente trabalho consiste em um estudo sobre a violência doméstica praticada em desfavor da mulher. Para tanto, utiliza-se a Lei 11.340/06, batizada Maria da Penha, como instrumento à análise do referido fenômeno que atinge parcela considerável da população feminina de diferentes classes sociais e culturas.

Enquanto o homem sofre violência nos espaços públicos e por um desconhecido, a mulher é vítima da agressão masculina dentro de casa, geralmente praticada por seu companheiro ou ex-companheiro. O fenômeno da violência contra a mulher não se baseia em idade, grau de instrução, classe social, sendo um problema relacionado à relação de dominação histórica masculina.

Atualmente, a violência doméstica contra a mulher tornou-se questão de interesse da sociedade como um todo, deixando, portanto, de ser um problema limitado ao ambiente familiar. Trata-se de preocupação social, tendo em vista os prejuízos causados na sociedade como um todo, pois, uma vez ocorrida, a agressão demanda serviços na área de saúde, afeta a economia do país, ocasionando baixo rendimento e maior número de faltas ao trabalho, entre outros inúmeros problemas perfeitamente identificáveis.

Dessa forma, pretende-se responder à seguinte questão: Em que medida a Lei Maria da Penha contribuiu para o aumento das denúncias por parte das mulheres vítimas de violência doméstica?

A explicação considerada mais viável para a pergunta, portanto, a hipótese do presente trabalho, é que a Lei Maria da Penha, por tratar mais detalhadamente a violência doméstica, irá encorajar as mulheres a denunciarem com maior freqüência seus agressores.

Tendo como base a Lei Maria da Penha e como referencial bibliográfico a autora Stela Valéria Cavalcanti, fez-se um estudo de campo em três instituições, quais sejam: Hospital Regional da Asa Norte, Delegacia Especial de Atendimento à Mulher e Casa Abrigo. 
Visando uma melhor compreensão do tema proposto, o trabalho foi dividido em três capítulos.

O primeiro capítulo demonstra o fenômeno da violência. Primeiramente fala-se da violência de forma generalizada como presente na história da humanidade e dentre as principais causas de morte de indivíduos em todo o mundo. Porém apenas recentemente veio despertar o interesse dos estudiosos.

Feita a análise de forma ampliada, parte-se para o estudo da violência contra a mulher nos espaços públicos e privados. Desde os primórdios às mulheres foram relegadas posições de inferioridade. A violência contra a mulher, bem como a violência doméstica não se restringe à pobreza, desigualdade social e cultural, se relaciona ao abuso de poder do agressor sobre a vítima.

O mundo assistiu os avanços na garantia de direitos das mulheres, contudo a violência contra elas persiste. A violência contra a mulher foi historicamente construída pela relação de desigualdade entre estas e os homens. Por outro lado, quanto à violência doméstica pretende-se demonstrar a dificuldade de tratamento do tema, vez que parte-se do pressuposto de que o ambiente familiar é um espaço harmônico de convivência de seus membros. Tal violência tem relação com a própria estrutura social, a qual estimula o homem a discriminar a mulher e conservar uma sociedade machista e patriarcal.

O movimento feminista levou para a área da saúde a preocupação com o fenômeno da violência, a qual criou ações voltadas para o atendimento das mulheres. A pressão pela atenção à violência de gênero dentro da saúde reivindica o atendimento não apenas ao que fisicamente se apresenta, mas que se aja nas causas por meio de uma gama de ações complexas associadas à violência de gênero.

No segundo capítulo faz-se um estudo sobre a família. Inicialmente analisase a família clássica, partindo-se da família romana caracterizada por seu caráter político e regida exclusivamente pela figura paterna. A tradição judaico-cristã impôs na sociedade um sentimento conservador, elegendo o casamento como o meio de o marido administrar os bens do casal. A mulher não só colocava seu patrimônio nas mãos do marido, mas também a sua capacidade e individualidade.

Seguindo a história das transformações da família demonstra-se que o casamento adquire maior liberdade, dependendo agora da vontade do homem e da mulher para compartilharem uma vida em comum. Com o advento da Constituição de 1988 ficou estabelecido como prioridade a valorização da personalidade e dignidade de cada membro da família, em detrimento dos aspectos patrimoniais. O Estado, 
atualmente, protege toda família fruto da vontade de um casal, sem que para isso estejam obrigados a se casarem. Porém, mesmo com os direitos garantidos pela Constituição de 1988 a subjugação feminina persiste ainda que camuflada e em menores proporções.

O feminismo mesmo não tendo lutado amplamente contra as injustiças sociais desde o seu surgimento, englobou um intenso processo que culminou nas transformações da vida tradicional, libertando as mulheres do confinamento do ambiente doméstico.

Também foi feito um apanhado sobre a situação da mulher no mercado de trabalho, dificultado pela inferioridade dos cargos ocupados, baixos salários e na grande maioria das vezes ocupação no mercado de trabalho informal como solução para conciliação entre as tarefas domésticas e a necessidade de ter uma remuneração. Por outro lado, com o passar dos anos algumas mulheres tomaram consciência de sua cidadania o que gerou na sociedade um caráter de instabilidade própria de processos de transição. Tais envolvimentos na causa feminina geralmente influenciam na criação de políticas públicas compensatórias para o combate à discriminação contra a mulher.

Por fim, no terceiro capítulo aprofunda-se no tema proposto pelo trabalho. Para tal, analisa-se primeiramente o surgimento das Delegacias de Defesa da Mulher, donde nota-se a participação do movimento feminista que insistiu na demonstração da falta de interesse pela violência contra a mulher, por parte do sistema judiciário.

De forma cada vez mais corriqueira, as estatísticas vêm demonstrando que o ambiente familiar não pode mais ser considerado como o espaço de harmonia, mas como um lugar em que ocorrem relações de opressão e ausência de direitos individuais.

Ainda que as dificuldades enfrentadas no funcionamento das delegacias especiais persistam, não se pode ignorar o fato de que elas constituem a principal política pública de combate e divulgação da violência contra a mulher. Menciona-se ainda, a necessidade de combinar o atendimento policial com outras áreas, como a psicologia e o serviço social.

Após passa-se a uma análise do sistema judiciário na punição dos crimes de violência doméstica, o qual inicialmente foi tipificado dentre os crimes de menor potencial ofensivo. Somente em 2004 o crime de violência doméstica foi efetivamente classificado e incluído no Código Penal como crime cometido no ambiente familiar. Apesar de não garantirem o fim da violência doméstica a definição de violência 
doméstica como crime possibilitou a divulgação das perversidades ocorridas nos lares, as quais permaneciam acobertadas pelo silêncio das vítimas e de seus familiares.

Finalmente, em 2006 foi publicada a Lei Maria da Penha recebida com grande entusiasmo como uma conquista de todas as brasileiras. Em cada etapa, a Lei dispõe como deve ser o atendimento para garantir a segurança das mulheres agredidas e os direitos que lhes são assegurados para que possam superar a situação vivida.

Portanto, fica demonstrado que o enfrentamento da violência contra as mulheres enfim passou a compor a agenda do governo brasileiro, contudo, para que todas as medidas formuladas sejam eficazes, antigos hábitos deverão ser superados, tais como o fim da cultura machista e patriarcal que discrimina as mulheres como seres inferiores. 


\section{CAPÍTULO I}

\section{FENÔMENO DA VIOLENNCIA}

A violência diminui a vida de várias pessoas em todo o mundo e causa dano à vida de outras milhares de vítimas. Ela não distingue raça, idade, renda ou espaço geográfico, portanto, qualquer indivíduo pode ser a próxima vítima. Para cada indivíduo que falece em decorrência da violência sofrida, diversas outras ficam com seqüelas ou convivem com problemas físicos, sexuais, reprodutivos e mentais.

A violência, provavelmente, sempre se fez presente na história da humanidade. Os danos são vistos em todo o mundo, vez que a cada ano mais de um milhão de indivíduos perdem a vida e tantos outros são feridos em virtude da violência. Dados mostram que a violência está entre as principais causas de morte de indivíduos entre 15 e 44 anos em todo o mundo.

Estudos fazem referência à existência de tendências individuais e genéticas para a predisposição ao comportamento violento, que interagem com fatores familiares, comunitários, culturais ou outros fatores externos, indicando situações em que a violência pode se estabelecer com maior freqüência.

A violência, mesmo fazendo parte da história da humanidade, não pode ser vista como um aspecto normal, passível de aceitação. Assim, instituições contrárias a ela foram surgindo, dentre elas, as instituições religiosas, filosóficas, legais e comunitárias, porém, nunca conseguiram alcançar total eficácia, mas contribuíram para a formação de uma civilização mais pacífica.

Há anos o Brasil apresenta como um dos fatores mais relevantes de mortalidade, a violência, a qual também causa doenças e alterações orgânicas e emocionais. A violência eleva a mortalidade pelas chamadas causas externas, sendo elas: as mortes por acidente de trânsito, de trabalho ou domésticos, por envenenamento, suicídios e homicídios, os quais revelam de forma mais explícita a idéia de violência.

A violência demonstra uma relação de agravamento decorrente do aumento das contradições sociais. São fatores que determinaram um atraso no desenvolvimento do Brasil, a distribuição desigual de renda, a estagnação da economia e o aumento da pobreza, problemas advindos principalmente, da década de 80. Tais acontecimentos incorrem no crescimento da violência estrutural, a qual se reveste do caráter da legalidade e leva à falsa compreensão de que os pobres são criminosos e delinqüentes, sendo que na verdade esses são os grupos sociais mais atingidos pela violência. 
É possível inferir que a violência faz parte da história da humanidade, mas veio a adquirir interesse por parte dos estudiosos recentemente. No século XIX, a normatização dos direitos humanos trouxe maior complexidade no estudo da violência e grande preocupação por parte de diversos setores representativos da população para a solução desse mal.

A violência existe em diversos momentos e lugares, ocorrendo tanto na esfera pública quanto na esfera privada. Alguns estudiosos sociais a visualizam como intrínseca à essência humana. A sociedade pode ter sido pensada como uma construção voltada para enfrentar e controlar o aumento da violência. Tem-se que as relações humanas estão vinculadas a um processo dinâmico e heterogêneo que desenvolvem ao mesmo tempo ações de reciprocidade e conflito. A falta de regulação institucional seguida por todos e imposta por um poder superior impossibilita o convívio humano, em que a falta de controle gera a guerra de uns contra os outros.

É importante ressaltar que o fenômeno da violência não pode ser analisado sem se levar em conta o quadro histórico-cultural em que se encontra. As normas de conduta são formuladas de acordo com as especificidades de cada sociedade, vez que existem atos que são considerados violentos por determinados grupos e que para outros não passam de atos normais. Como exemplo, pode-se citar a naturalidade como era encarada a violência contra a mulher dentro das relações familiares, em uma época em que o homem exercia poder sobre sua filha e esposa.

A essência do senso comum sobre a violência está em considerar que esta faz como vítimas os que se caracterizam como sendo: pobres ou fracos. Dessa forma, a noção de violência passa por uma construção desigual dentro da sociedade, associandose com determinadas categorias sociais. Ela ocorreria em número desproporcional entre os pobres e fracos, quando comparados aos ricos e fortes. A falta de diálogo também está relacionada a freqüência dos casos de violência. Aqui, o costume, a conversa ou a lei são inutilizados a favor de uma relação de poder e força física para maltratar a vítima e mantê-la sob seu domínio (CAVALCANTI, S. V. S. F. 2007, p. 29).

Analisando o vocábulo violência, Stela Cavalcanti demonstra sua origem do latim, em que o prefixo vis designa força. A palavra refere-se ainda, ao excesso, demonstrando que para além de uma simples força, a violência pode ser definida pelo abuso da força. Portanto, referida autora, assim descreve: 
É um ato de brutalidade, abuso, constrangimento, desrespeito, discriminação, impedimento, imposição, invasão, ofensa, proibição, sevícia, agressão física, psíquica, moral ou patrimonial contra alguém e caracteriza relações intersubjetivas e sociais definidas pela ofensa e intimidação pelo medo e terror. (CAVALCANTI, 2007, p.29)

Seguindo, ainda, o entendimento do termo violência, Stela Valéria

Cavalcanti citando Hannah Arendt, afirma que:

Poder, força, autoridade e violência - nada mais são do que palavras a indicar os meios pelos quais o homem governa o homem [...]. Se nos voltarmos para os debates sobre o fenômeno do poder, descobriremos logo que existe um consenso entre os teóricos políticos da esquerda e da direita de que a violência nada mais é do que a mais flagrante manifestação do poder. (CAVALCANTI, 2007, p.29)

\subsection{A violência contra a mulher dentro e fora do ambiente doméstico}

Desde os tempos mais remotos às mulheres são relegadas posições de inferioridade dentro da sociedade. Assim, sabe-se que durante o século II d.C., os homens das classes mais altas do Império Romano viviam observando o mundo de uma posição de domínio indiscutível. As mulheres, os escravos e os bárbaros eram vistos como seres diferentes e inferiores a esses homens.

A visão de superioridade dos homens perante as mulheres era explicada pela própria natureza, em que os médicos afirmavam que os fetos masculinos eram aqueles que tinham realizado seu potencial pleno e formariam as características mais fortes, como a coragem e a força no pensar e no agir. Por sua vez, as mulheres eram vistas como homens imperfeitos, sendo mais prejudicadas nas formas que os homens. Tais afirmações serviam para provar que a inferioridade feminina advinha de uma natureza incontestável. Contudo, esse entendimento não era usado apenas para manter a posição de inferioridade da mulher, mas também para que o homem se esforçasse para nunca deixar de ser viril, adotando comportamento comparável ao feminino. Portanto, o sexo masculino estava proibido de agir de forma delicada, vivendo sob constante vigilância da sociedade, os senhores de um mundo subjugado, sendo obrigados a se mostrarem rudes nos gestos, no andar e na fala.

A chegada do século XXI trazia a esperança que os noticiários anunciariam a clara diminuição da violência urbana, pois a sociedade estaria em sua plena evolução. Entretanto, os jornais mostraram a cruel realidade do aumento das várias formas de violência mais visíveis, sem mencionar os fatos quase nunca divulgados como o 
aumento do desemprego, da prostituição infantil, da diferença salarial entre homens e mulheres e da prática da violência doméstica, entre outros. Tais fatos são abafados pelo senso comum.

Nesse sentido, Stela Cavalcanti, mencionando o entendimento de Marilena Chauí, assim explicita:

\begin{abstract}
O senso comum é um conjunto de crenças, valores, saberes e atitudes que a sociedade julga naturais porque transmitidos de geração a geração, sem questionamentos. Em algum momento da vida foi dito como são e o que valem as coisas e os seres humanos, como devem ser avaliados e tratados e nós aceitamos estas informações sem contestação. Quando o senso comum se cristaliza como modo de pensar e de sentir de uma sociedade, forma o sistema de preconceitos. Esse sistema de preconceitos ou representações permeia todas as relações sociais, podendo afetar de forma profunda e negativa estabelecendo diferenças entre as pessoas, negando direitos fundamentais e gerando conflitos [...] (CAVALCANTI, 2007, p.30)
\end{abstract}

As mais variadas formas de preconceito existentes na sociedade são conectadas como forma de marginalizar determinados grupos, como por exemplo, pela classe social, gênero ou raça. As conseqüências advindas do preconceito por cor e gênero são o tratamento de inferioridade dispensado a negros e mulheres, refletindo na deficiência de educação, e, portanto, em pouca oportunidade de empregos bem remunerados.

Nota-se que, dentre as formas de violência, a violência contra a mulher está incluída desde 1991 como uma questão de saúde pública, vista pela Organização PanAmericana de Saúde como fator de adoecimento das mulheres. A violência contra a mulher pode ser classificada como resultado do conflito de gênero ou como violência doméstica, familiar, sexual, psicológica ou física.

A violência contra a mulher, bem como a violência doméstica, não têm relação restrita à pobreza, desigualdade social e cultural. Tais fenômenos vinculam-se ao preconceito, discriminação e abuso de poder do agressor sobre a vítima, a qual se encontra em posição de vulnerabilidade na relação social em virtude de suas características, tais como, o porte físico.

Com a Declaração Universal de 1948, o mundo ocidental começou a dispor em suas legislações, o reconhecimento a diversidade biológica, social e cultural dos indivíduos, elaborando declarações e pactos específicos para as mulheres. Assim, os Estados signatários se comprometem em promover a igualdade entre os sexos, lutar contra a discriminação e a violência contra a mulher. Contudo, apesar dos avanços na garantia dos direitos das mulheres, a violência física e psicológica continua a atormentar a vida de muitas delas. 
Segundo Stela Cavalcanti:

A violência contra a mulher é qualquer conduta - ação ou omissão - de discriminação, agressão ou coerção, ocasionada pelo simples fato de a vítima ser mulher, e que cause dano, morte, constrangimento, limitação, sofrimento físico, sexual, moral, psicológico, social, político ou econômico ou perda patrimonial. Essa violência pode acontecer tanto em espaços públicos como privados. (CAVALCANTI, 2007, p.36)

Equivoca-se quem confunde a violência contra a mulher com a violência doméstica. Tem-se que a violência contra a mulher possui um conceito mais amplo, sendo definida pela Convenção sobre a Eliminação de Todas as Formas de Discriminação contra a Mulher como: "qualquer ato de violência que ocasione algum prejuízo ou sofrimento físico, sexual ou psicológico às mulheres, incluídas as ameaças de tais atos, coerção ou privação arbitrárias da liberdade que ocorram na vida pública ou privada”.

A Convenção Interamericana para Prevenir, Punir e Erradicar a Violência Contra a Mulher retrata a violência contra a mulher como sendo historicamente construída pela relação de desigualdade entre estas e os homens. O documento afirma ainda, que a eliminação dessa forma de violência é condição imprescindível para o desenvolvimento individual e social da mulher, bem como sua plena e igualitária participação em todas as esferas da vida.

O fato de pertencer ao sexo feminino, com todas as suas determinações construídas socialmente, contribui para a vulnerabilidade a um tipo específico de violência, a violência contra a mulher. Dessa forma, o fato de se nascer mulher requer o cumprimento dos modelos culturais estabelecidos e o desvio de tais modelos justificaria a violência. A condição de gênero faz surgir um tipo de violência no espaço socialmente estabelecido para as mulheres, no espaço privado, na família, no domicílio.

A violência de gênero demonstra a configuração de papéis desempenhados por homens e mulheres na sociedade. A modificação ocorrida nas relações de gênero, pela transformação na construção social do feminino, são caracterizadas por uma tensão e reflete-se em violência doméstica cometida por parceiros e ex-parceiros.

Este entendimento da violência contra a mulher como uma violência de gênero se refere à construção social do feminino, que determina a crescente ocorrência da violência contra a mulher. É fato que a violência praticada pelo homem contra a mulher no âmbito familiar existe há tempos, vez que prevalecia o entendimento de que a mulher deveria ser submissa ao marido. 
A violência doméstica contra a mulher classifica-se como uma violência familiar, praticada por vezes por seu companheiro que exerce uma relação de poder e dominação sobre ela. Tal violência ainda hoje não é vista em sua complexidade, ignorando-se na maioria dos casos a gravidade de suas conseqüências. Ela tem como agente agressor alguém que a vítima mantém uma relação de afetividade, não sendo necessariamente o companheiro, mas podendo ser o pai, padrasto ou outra pessoa que não um estranho. Contudo, na maioria dos casos, o que se tem é a figura do companheiro ou ex-companheiro como o sujeito ativo da agressão.

Conforme demonstrado por Stela Cavalcanti:

Violência doméstica e familiar é a ação ou omissão que ocorre no espaço de convívio permanente de pessoas, com ou sem vínculo familiar, inclusive as esporadicamente agregadas. É aquela praticada por membros de uma mesma família, aqui entendida como a comunidade formada por indivíduos que são ou se consideram aparentados, unidos por laços naturais, por afinidade ou por vontade expressa. (CAVALCANTI, 2007, p.40)

A dificuldade quando se aborda o tema violência doméstica está no ambiente em que ela ocorre, ou seja, na própria família. Presume-se que o ambiente familiar é um local reservado para a convivência harmônica de seus membros, resguardado da interferência do mundo exterior. Porém, a partir do momento que algo de interesse público ocorre no interior do lar, necessariamente ocorrerá uma relação de desconforto para aquela família. Dessa forma, o ambiente que antes era de interesse exclusivo de seus membros, passa a ser um local de investigação policial ou científica.

A presunção do ambiente doméstico como um lugar de harmonia justifica a falta de atenção dada às violências ali ocorridas. Tal entendimento vinculado a outros mitos, dentre eles o de que a violência doméstica raramente ocorre e, ocorrendo limitase a famílias ditas anormais ou de classes economicamente menos favorecidas e que os agressores são indivíduos com perturbações psíquicas, não deixam a sociedade enxergar a gravidade do problema.

Ressalte-se que, uma das grandes questões intrigantes sobre a violência doméstica contra a mulher está na falta de visibilidade dada ao tema. Isso se deve ao fato de tal violência estar inserida na esfera privada e estar atrelada à questão da relação de poder existente na violência baseada no gênero. Dessa forma, não é possível tratar igualmente um agressor estranho e um agressor que convive com a vítima, vez que a possibilidade de o mesmo agressor voltar a cometer a violência é visivelmente superior quando se trata de um conhecido. 
A violência doméstica na maioria das vezes aparece como vinculada a problemas dos agressores, com o álcool, as drogas ilícitas e o ciúme, porém, a base de todo o problema encontra-se na forma como a sociedade valoriza o papel masculino nas relações de gênero. Os indivíduos aprendem desde crianças quais comportamentos pertencem a cada sexo, sendo assim, é possível afirmar que a violência doméstica tem relação com a própria estrutura social, a qual estimula o homem a discriminar a mulher. O fenômeno é muito complexo para se explicar tendo por base justificativas como o alcoolismo ou transtorno psicológico do agressor, pois aqui a violência é exercida especificamente contra a mulher e não a qualquer pessoa.

Faz-se necessário questionar o que pensam os formuladores de políticas públicas, vez que ainda existe a distinção de quais papéis serão desempenhados por homens e mulheres. Ocorre que, desde 1950 as mulheres começaram a discutir a opressão e discriminação a que se submetiam. Houve a criação de movimentos e ações de resistência, baseados no reconhecimento da condição social das mulheres como determinada pelo patriarcalismo e capitalismo. Assim, as mulheres passam a reivindicar acesso aos direitos que lhes foram negados, requerendo a inclusão das questões de gênero nas discussões políticas a nível internacional, nacional, regional e local.

A crueldade no tratamento às mulheres sem que haja uma justificativa consistente, mas apenas pelo fato de pertencerem ao sexo feminino, é uma prática recorrente em todo o mundo. Violam-se os direitos femininos em nome da família, da religião e da cultura, sem que se estabeleça uma severa punição compatível com a tirania do ato. Nesse sentido, Stela Cavalcanti traz como exemplo, a chocante história de mulheres bangladesas que sofrem a agressividade dos homens escolhidos mediante negócio familiar para serem seus maridos. A recusa em não se casar ou o não pagamento do dote devido, gera uma vingança a base de ácido sulfúrico que é lançado no rosto das prometidas desfigurando-as e estigmatizando-as socialmente. Os agressores, por sua vez, nada sofrem além de uma multa estipulada em um valor irrisório.

A Organização das Nações Unidas realizou ao longo dos anos, conferências internacionais incluindo como debate a questão dos direitos das mulheres. A primeira conferência ocorreu em 1979, conhecida como Convenção sobre a eliminação de todas as formas de discriminação contra as mulheres. Visando a garantia dos direitos humanos e liberdades fundamentais das mulheres, foi realizada a III Conferência Mundial sobre a Mulher, no ano de 1985, em Nairobi. A Conferência realizada em 1994 no Cairo 
abordou os direitos sexuais e reprodutivos que passam a ser incluídos dentre os direitos humanos. Em Pequim/Beijing a ONU apresentou a IV Conferência Mundial, em 1995. A Plataforma de Ação, decorrente da Conferência em Beijing, traz algumas medidas que os governos signatários se responsabilizaram em realizar em um prazo de cinco anos, incluindo aqui ações para o combate à violência.

No decorrer dos anos, as transformações ocorridas na sociedade modificaram a compreensão do que se considerava correto e o que seria ato de violência sujeito à regulação social e punição. A história mostra que os fatos ocorridos na esfera privada não seriam passíveis de intervenção do Estado e nem da sociedade, tendo em vista as crenças que justificavam a superioridade do homem sobre a mulher e a violência como forma de educar a mulher nos casos em que essa se negasse a cumprir as obrigações de esposa, impostas socialmente.

Dessa forma, o fenômeno da violência doméstica, desde sempre, estimulou o silêncio por parte de suas vítimas. Não obstante, o silêncio dessas vítimas ainda as desestimula na busca por ajuda junto a instituições competentes, tendo em vista a falta de apoio dada pela sociedade. O meio em que essas mulheres estão inseridas as convence que o silêncio sobre o sofrimento é a melhor solução para o problema.

A postura silenciosa assumida pela vítima de violência doméstica pode ser interpretada como uma forma de resistência ao sofrimento. Por outro lado, o agressor é visto em sua fragilidade e pouca resistência à frustração, agindo violentamente por perder o controle ou por ser suscetível à influência externa, muitas vezes os próprios amigos.

O fato de a vítima não procurar vencer a situação de violência, não demonstra que seja esse o seu desejo. Apesar da existência de meios para fazer cessar a violência, os obstáculos encontrados no caminho frustram a reação. Ocorrem críticas de familiares, amigos, vizinhos e até a violência institucional quando chegam a buscá-la.

\subsection{Repercussões na saúde}

Sabe-se que a violência doméstica configura-se como um crime encoberto, porque os dados que chegam ao conhecimento público não mostram a real gravidade do problema. Por várias razões pessoais as mulheres agredidas evitam denunciar os agressores, principalmente se este for o próprio marido, do qual dependem emocionalmente ou financeiramente. Da mesma forma, a falta de instituições voltadas para o tratamento das vítimas e reeducação do agressor inibe as denúncias. 
O movimento feminista levou para a área da saúde a preocupação com o fenômeno da violência, tendo tal área se responsabilizado pelos direitos sexuais e reprodutivos. Dessa forma, foram criadas ações voltadas para o atendimento dos grupos reivindicadores, especificamente as mulheres.

Em meio a lutas sociais, a preocupação com dados epidemiológicos trouxeram o fenômeno para o conhecimento público. Assim, a formação dos movimentos sociais deu visibilidade à violência, principalmente a praticada em desfavor das mulheres e crianças. Importante participação nesse contexto histórico tem o movimento feminista, o qual lutou pela ampliação dos direitos das mulheres, sendo a maior conquista as garantias estabelecidas na Constituição Federal de 1988. Foram lutas que deram visibilidade ao problema da violência e também incentivaram a criação de ações preventivas, demonstrando a ligação existente com a questão da saúde.

Em sua raiz e exteriorização, a violência não se configura como um fenômeno da saúde pública e sim como um fato que acompanha a história da humanidade. Porém, com o tempo ela passa a ocupar um espaço dentro da saúde, na medida em que ela prejudica tanto individual quanto coletivamente e requer, para o seu combate, elaboração de políticas públicas específicas e formulação de serviços próprios na área.

A pressão pela atenção à violência de gênero dentro da saúde reivindica o atendimento não apenas ao que fisicamente se apresenta, como as lesões e traumas, mas que se aja nas causas por meio de uma gama de ações complexas. Sendo assim, foi enviada à área de saúde uma lista de problemas que afetam a saúde da mulher, dentre eles, as agressões conjugais, abusos sexuais, físicos e psicológicos, dentre outros associados à violência de gênero.

Existe a necessidade de um planejamento que considere a violência e a saúde, vez que a violência se configura como uma ameaça à vida e gera uma sobrecarga ao sistema de saúde com os inúmeros casos de doenças e incapacidades causadas em suas vítimas. A violência em suas diversas formas de manifestação prejudica a saúde, representando um dano maior a qualidade de vida humana, por ameaçar a vida, gerar enfermidades, danos psicológicos e em última instância provocar a morte.

Apesar da impossibilidade de se definir precisamente o custo da violência para o mundo, pode-se afirmar que são bilhões de dólares de custos anuais com tratamentos de saúde, somados a outros bilhões gastos devido aos dias não trabalhados, imposição e cumprimento da lei e investimentos perdidos, afetando a economia do país. 
Contudo, para o sofrimento humano não existe estimativa de custo, não se definindo valores monetários. Diariamente os noticiários informam a ocorrência de grande número de violência ao redor do mundo, mas permanece invisível uma quantidade bem maior de agressões sofridas dentro dos lares, ambiente de trabalho e até em instituições sociais e médicas comprometidas com o cuidado das vítimas.

É considerável o número de mulheres que procuram os serviços de saúde, queixando-se de dores relacionadas a situações de violência vividas no próprio lar. Mesmo que não relate ser vítima de violência doméstica, na área de saúde tem se percebido grande ligação entre essa forma de violência e a procura por atendimento nas unidades de saúde. Assim, é de grande importância a capacitação dos profissionais para reconhecer, atender e tratar as pacientes que podem estar com sinais relacionados a abuso ou agressão.

Mesmo que muitas dessas agressões não tenham conseqüências fatais, sempre haverá um dano seja ele físico ou psicológico. O que se verifica é o caráter repetitivo da violência doméstica, demandando, portanto, serviços de saúde com certa freqüência. Entretanto, ações específicas na área da saúde continuam precárias, existindo pouca preocupação com a melhora dos serviços que atendam tais casos.

O mito de que os maus-tratos no ambiente familiar são raros, limitados a determinados locais envoltos na marginalidade e com tipos específicos de agressores que possuem problemas com álcool e drogas, não refletem a realidade. Diversas pesquisas feitas sobre o perfil dos agressores e vítimas de maus-tratos revelam que este fato ocorre em todas as culturas e que o nível econômico e intelectual não pode ser levado em consideração para determinar a sua ocorrência.

Dados colhidos no estado do Rio Grande do Sul são assim citados por Stela Cavalcanti:

[...] No estado do Rio Grande do Sul, Relatório Azul elaborado pela Assembléia Legislativa (1998), com dados de 1994 e 1998, revela mais de mil casos anuais de estupro informados a polícia. Dados fornecidos pela Delegacia da Mulher, para a cidade de Porto Alegre, no ano de 2000 (Relatório Azul, 1999/2000), demonstra a existência de 2469 ocorrências, em que aparecem os seguintes dados: lesão corporal, 37,4\%; ameaça, 40,1\%; estupro, 1,0\%. Uma amostra de 72 mulheres que buscaram ajuda na emergência de um hospital geral, no Rio de Janeiro, por violência doméstica, constatou que o marido foi o agressor, em 56,9\% dos casos, seguido dos exmaridos e namorados. Em 70,4\% dos casos houve agressões por espancamento, principalmente na face e na cabeça. (CAVALCANTI, 2007, p.52/53) 
A vítima de violência doméstica, apesar de ter consciência da crueldade a que está exposta, não se sente motivada a denunciar o responsável pela agressão, pois tem medo de se arrepender e lhe falta apoio para essa iniciativa. Pesa sobre a mulher a imputação de responsabilidade pela desestruturação familiar, dependendo da escolha que fizer: denunciar ou assumir uma postura silenciosa.

Historicamente os casos de violência doméstica eram solucionados pelas delegacias de mulheres. Os crimes ocorridos entre companheiros eram comparados aos crimes praticados entre desconhecidos, sendo que a violência não era vista como um ato de crueldade e sim como defesa da honra masculina. Assim, primeiramente a violência não estava dentre as questões relevantes para a saúde. Os casos que chegavam até a rede de saúde deveriam se apresentar como uma doença visível que justificasse a intervenção médica, do contrário o fato seria considerado como englobado na ordem do social ou do psicológico.

Atualmente, a violência contra a mulher está sendo reconhecida como relevante para a saúde e qualidade de vida. Cada caso deverá ser analisado em sua complexidade para uma intervenção conforme a violência doméstica seja compreendida e acolhida. A violência pode trazer resultados mais leves decorrentes de um empurrão e até gravíssimos que têm como conseqüência a morte da vítima.

A violência contra a mulher causa danos que vão de traumas a lesões corporais, estando relacionada às causas de aborto, gravidez indesejada, abuso de drogas e álcool, depressão, insônia, suicídio, entre outros males. Com relação aos danos emocionais, não existe vinculação entre o momento que se vive a agressão e o trauma causado, isto é, ter passado ou estar passando por essa situação não influencia na intensidade de ordem emocional, em ambos os casos haverá repercussões.

A mulher deve ser tratada como um sujeito de direito e, quando for necessário buscar ajuda nos serviços de saúde, sendo esses responsáveis pelo atendimento eficaz daquela que não deseja mais conviver com a violência. Da mesma forma, existe a necessidade de um maior engajamento para a formulação de políticas públicas para o combate a violência contra a mulher exercida no espaço privado, a qual não se faz relevante exatamente por sair do âmbito público, gerando uma idéia deturpada de que não se configura como demanda para a intervenção de políticas públicas.

É notável que em muitos casos o serviço de saúde existe, porém, não possui o atendimento que as mulheres precisam, por vezes devido à discriminação e 
preconceito. Na maioria dos casos, os serviços de saúde não garantem o tratamento necessário às mulheres vítimas de violência, isso porque, os profissionais não são capacitados ou são omissos e, há preconceito com a afirmação de que o assunto foge à competência dos profissionais de saúde. Esse é o caso das mulheres que sofrem violência sexual, as quais buscam o serviço de aborto reconhecido legalmente, mas são surpreendidas com a insuficiência do atendimento.

Diversos problemas existentes na área da saúde estão relacionados à desigualdade de gênero. Nesse ponto, muitas mulheres se vêem prejudicadas no seu sentimento de bem-estar psicológico, biológico e social, em que as causas nem são identificadas. Tal desconforto muitas vezes está vinculado à opressão sofrida com seus companheiros, ou seja, nas relações de gênero.

Nota-se que os programas de governo ou planejamento de políticas na área de saúde, atendem prioritariamente as demandas referentes ao atendimento maternoinfantil. São garantidos cuidados com o período reprodutivo da mulher e com as crianças. Assim, caso a demanda da mulher seja outra, o atendimento não será considerado como prioritário.

O movimento de mulheres para a inclusão da violência como questão de saúde no Brasil colaborou significativamente para a construção do Programa de Atenção Integral à Saúde da Mulher (PAISM). Tal programa atende aos direitos sexuais e reprodutivos. Ele garante importância ao tema da violência e impõe um tratamento próprio para o tema dentro do serviço público.

O PAISM foi assumido pelo Ministério da Saúde a partir de 1983, tendo como preocupação inicial o crescimento populacional. Contudo, o PAISM desde então é visto como de pouca implementação no país, as experiências são isoladas e descontínuas, sendo necessárias maiores decisões políticas para a efetivação das propostas.

No Distrito Federal o PAISM da Regional Norte é controlado pelo Ministério da Saúde e Secretaria da Saúde. Até 1960 a preocupação desse Programa era com o cuidado materno-infantil. Atualmente conta com serviços de planejamento familiar e prevenção ao câncer de útero e mama. O problema relatado pela coordenadora está na má-fé da gestão administrativa, ocorrendo desvio de recursos que prejudicam o pleno funcionamento do Programa. 
Há no Distrito Federal o Programa de apoio às vítimas de violência em suas diversas formas de manifestação. Denomina-se PAVI, o Programa de Violência, o qual possui ramificações, visando à efetividade no atendimento.

O Programa Margarida é uma das espécies do PAVI para atendimento de mulheres vítimas de violência doméstica, violência sexual e física e crianças vítimas de violência. Localizado no Hospital Regional da Asa Norte, HRAN, o Programa conta com a atuação de uma equipe multidisciplinar formada por pediatra, psicólogo, assistente social, auxiliar de enfermagem, estagiário de psicologia. Toda quarta-feira pela manhã, é feito o acolhimento dos interessados, por ordem de chegada. A procura ocorre espontaneamente ou, em casos como o estupro que a entrada é pela emergência, o próprio médico encaminha.

Nos casos específicos de violência doméstica, após o acolhimento o profissional verifica o grupo adequado a ser freqüentado por cada mulher. Contudo, antes de começarem a freqüentar os grupos, as mulheres recebem atendimento psicológico individual. Ressalte-se que durante o acolhimento cada mulher é orientada a denunciar o agressor, tendo por base a Lei Maria da Penha.

Conforme disposto no Projeto de Lei nº1368 de 2004, para cada vítima de violência que procura o atendimento no Programa Margarida, preenche-se um formulário oficial para notificação de todos os casos ocorridos no Distrito Federal. O preenchimento da Notificação Compulsória da Violência contra a Mulher é feito pelo profissional de saúde que realizou o atendimento e será encaminhada em três vias, sendo que a primeira seguirá para o arquivo especial da violência contra a mulher, a segunda será enviada, somente mediante autorização expressa da vítima, à Delegacia de Defesa da Mulher, a terceira via será entregue à própria vítima por ocasião da sua alta.

A ficha de Notificação Compulsória deve conter as seguintes informações: identificação da vítima, identificação do acidente, identificação da violência ou suspeita de violência, dados do agressor, dados da ocorrência, evolução do caso. Uma vez que tais dados são entregues ao arquivo especial da violência contra a mulher, deverão ser mantidos em sigilo.

A justificativa para aprovação do referido Projeto de Lei é a proteção a mulher vítima de violência doméstica, garantindo o correto atendimento por parte das autoridades competentes. Objetiva-se uma maior clareza dos dados sobre a violência doméstica cometida em desfavor das mulheres no Distrito Federal, sendo acessíveis à sociedade, visando melhores formas para minimizar a atual situação para que as 
mulheres tenham maior proteção, respeito e dignidade. É necessário o engajamento do Estado e da sociedade no combate a essa forma de violência, ajudando as vítimas na recuperação de sua auto-estima. Sendo assim, o setor de saúde é responsável pelo acolhimento das vítimas, procurando diminuir a dor e evitar maiores danos. 


\section{CAPÍTULO II}

\section{A FAMÍLIA}

A família é a forma mais antiga de agrupamento dos indivíduos, tanto do ponto de vista biológico como do social. Contudo, a palavra família tem se revestido de variados conceitos, sofrendo variações no tempo e no espaço (PEREIRA, C. M. S. 2001).

A civilização romana foi a mais importante nos estudos sobre a família na antiguidade. Tal sociedade caracteriza-se pela forma singular em que o pai reconhecia o filho, qual seja, pela apresentação ao altar doméstico, demonstrando que o filho daria seguimento ao culto ancestral. A família romana tinha caráter político e era regida exclusivamente pela figura paterna.

Observa-se que a família, nos diferentes períodos da história, sofreu profundas modificações em sua estrutura. Assim, antigamente era compreendida por todos aqueles que se submetiam a um chefe comum e se reuniam para adorar os antepassados presentes no altar de cada lar. Posteriormente, a família foi se restringindo aos pais e filhos ligados pelos laços biológicos, porém hoje a união é formada, sobretudo, através dos laços afetivos.

A tradição judaico-cristã impôs na sociedade um sentimento conservador, em que a Igreja entende o casamento como um sacramento e o Estado o classifica como instituição jurídica. O casamento era a forma encontrada, pela sociedade do início do século passado, de transmitir o patrimônio entre os que possuem o mesmo sangue. $O$ matrimônio unia os bens do casal, sendo administrado exclusivamente pelo homem. A mulher não só colocava o seu patrimônio nas mãos do marido, mas também a sua capacidade e individualidade, sendo, ainda, obrigada a usar o nome do marido. O trabalho apenas era permitido mediante autorização do cônjuge, restando-lhe, portanto, as tarefas domésticas, cuidar do lar, servir o marido e criar os filhos. Cabe aqui ressaltar que o casamento era indissolúvel, o desquite rompia, mas não desfazia os laços invioláveis do matrimônio (DIAS, M. B. 2004).

A partir do momento em que o status e a fortuna deixaram de ser adquiridos mediante a união de grupos familiares e passaram a depender da proximidade com o príncipe, da carreira civil ou militar, da fluência nos negócios, a realização do casamento toma outra forma. Nota-se que o casamento adquire uma maior liberdade, na escolha da esposa, na vontade do casal e nas razões individuais para desejá-lo. O 
casamento vai fazendo-se útil para os que quisessem compartilhar a vida, tendo ajuda mútua e apoio moral entre os companheiros.

A manifestação de vontade entre o casal vai demonstrando que os laços matrimoniais são estabelecidos livremente. No mundo helenístico a independência da mulher com relação a seu pai, pode ser notada se comparada ao que ocorria na era clássica. O direito de uma filha casada guiar-se por conta própria sem a intervenção da autoridade paterna começa a ser afirmado.

Tomando as relações familiares como parâmetro, nota-se que as modificações sociais implantaram um novo comportamento humano. O conceito de família foi se distanciando do tradicional, na medida em que foi surgindo o movimento feminista, os métodos contraceptivos, a evolução da engenharia genética. O Estado acompanhou a evolução, valorizando mais a pessoa humana, deixando de lado as concepções impostas por uma sociedade regida pelo entendimento cristão. Hoje, valoriza-se, sobretudo, a afetividade, porquanto o vínculo entre as pessoas só é possível por meio dela, o fim do afeto apenas consegue gerar a discórdia no seio familiar (DIAS, M. B. 2004).

O intuito dessa breve explanação é dar uma visão geral sobre as transformações por que tem passado a família e estabelecer o papel assumido pela mulher no ambiente doméstico em meio à sociedade tradicionalmente patriarcal. Conclui-se que, as vontades femininas ocuparam lugar secundário e, com a celebração do casamento ocorria a legitimação do exercício de poder do marido sobre a esposa, sendo tais laços indissolúveis.

\subsection{Conceito tradicional}

No Direito Romano a organização da família era baseada na religião. Para que o indivíduo fosse reconhecido como filho, o pai deveria lhe apresentar ao altar, demonstrando que ele seria o responsável pela continuidade do culto religioso. Assim, o reconhecimento da filiação não era baseado na consangüinidade, mas no pertencente ao culto ancestral (PEREIRA, C. M. S. 1998).

Cada família cultuava um deus próprio, rito esse restrito a seus membros, sendo proibido a qualquer indivíduo pertencer a mais de uma família. A responsabilidade de continuar o culto era transmitida apenas entre os indivíduos do sexo masculino. (PEREIRA, C. M. S. 1998). 
Em Roma o casamento era um acontecimento de interesse exclusivamente familiar, não havendo interferência dos poderes públicos para seu reconhecimento. Naquela época, encontrava-se dentre as finalidades do casamento a transferência de autoridade exercida pelo pai sobre a filha, ao marido, portanto, configurava-se como um negócio celebrado entre dois homens simbolizando a troca do chefe de família.

Não era o amor que unia uma família romana, mas o princípio da autoridade, caracterizando-a como uma entidade política. Aqueles sob os quais a autoridade do pai fosse dirigida eram os verdadeiros membros da família. O filho era tido como parente de sua mãe apenas por ela estar submetida à autoridade do pai, chefe da família (MIRANDA, P. 2000).

A finalidade do casamento estava na obtenção de direitos e manutenção do status, demonstrando que eram as classes mais altas que tinham total interesse em sua celebração. Dessa forma, a cerimônia era necessária àqueles que precisassem garantir que a transmissão de seu patrimônio seria para seus descendentes e para que fosse dada continuidade à casta dos cidadãos.

Por volta do século IV a.C., no Egito helenístico, as obrigações decorrentes do casamento impunham à mulher: obediência, proibição de sair de casa sem permissão e obrigação de não desonrar o marido, entre outras. Em contrapartida, o marido deveria manter sua mulher, não levar uma concubina para casa, não maltratar sua esposa e não ter filhos dos relacionamentos que tivesse fora do casamento.

A figura do pai englobava as funções de sacerdote, juiz e chefe ao mesmo tempo. Todos estavam sujeitos à autoridade do pater, que também exercia a função de administrador do patrimônio familiar. Todo o patrimônio se concentrava nas mãos do pai (LISBOA, R. S. 2004).

Alguns anos depois, com o início da transformação da Urbs em Imperium, o culto doméstico começa a perder força. A família romana vai se modificando na medida em que o pater deixa de exercer total controle sobre seus filhos e mulher (WALD, A. 2000).

Com o passar dos anos o casamento no mundo helenístico vai ocupando espaço na esfera pública. Assim, a autoridade estritamente familiar sofre uma ruptura, surgindo leis que normatizavam o matrimônio. Destaca-se a lei de adulteriis, a qual punia a mulher casada que se relacionasse com outro homem e, da mesma forma, o homem que tivesse relação com uma mulher casada. Contudo, o homem casado que se relacionasse com uma mulher não casada não recebia nenhum tipo de punição. 
Primeiramente, os vínculos jurídicos e os elos biológicos configuravam-se como de maior importância que os laços afetivos na composição da família. Jacqueline Filgueras Nogueira observa que: “o afeto na concepção de família tradicional era presumido, tanto na formação do vínculo matrimonial quanto na sua manutenção. $\mathrm{O}$ afeto ficava, pois, à sombra da celebração, podendo existir ou não nas relações familiares” (NOGUEIRA, J. F. 2001).

Aos filhos foram concedidos direitos sucessórios e alimentícios e, quanto às mulheres, adquiriram maior autonomia, começando a participar da vida social e política. Assim, ao longo dos anos foi se garantindo maior proporcionalidade entre os direitos e deveres dos homens e das mulheres. As mulheres passaram a exercer influência sobre os filhos, que antes se encontravam apenas sob a autoridade do pai (WALD, A. 2000).

Perante o direito canônico, o divórcio configurava-se como contrário à vontade de Deus e como sendo nocivo à índole da família, bem como prejudicial aos filhos, pois o casamento além de ser um contrato é um sacramento. Assim, pelas regras do direito canônico o casamento é visto como sacramento, sendo que o divórcio apenas era reconhecido aos infiéis, caso em que o matrimônio não era visto como sagrado. Pouco a pouco a influência cristã busca ocupar espaço no direito romano, contudo, demanda certo tempo para conseguir impor seus ideais (PEREIRA, C. M. S. 1998).

Findo o Império Romano, iniciada a invasão bárbara, a igreja católica conquista seu espaço. Na Idade Média, os vínculos familiares se pautam exclusivamente pelas regras do direito canônico, sendo que, do século $X$ ao século $X V$, apenas o casamento religioso era reconhecido. Contudo, entre a concepção católica e a medieval existia uma diferença, para a igreja o importante era que houvesse acordo entre as partes, enquanto que, para a sociedade medieval deveria haver consenso entre as partes e seus parentes, pois o casamento exercia influência política e econômica na sociedade (WALD, A. 2000).

No período anterior à Revolução Industrial, predominava a atividade artesanal que era exercida pelos membros da família em conjunto. Com o surgimento das fábricas, o artesanato deixa de garantir o sustento da família, obrigando seus membros a procurarem emprego nas fábricas. Dessa forma, as mulheres começam a procurar emprego longe de casa e os filhos que antes eram incumbidos de dar continuidade à atividade desenvolvida por seus pais, começam a procurar outras formas de trabalho (LISBOA, R. S. 2004). 
Devido às modificações ocorridas nesse período, os trabalhadores foram se vendo cada vez mais à mercê dos interesses dos empregadores e, portanto, começaram a se revoltar. As mulheres e os jovens, nesse momento, também começam a lutar por seus direitos, gerando grandes modificações nas relações familiares.

Analisando a família no século $\mathrm{XX}$, tem-se que as guerras mundiais contribuíram para sua notável modificação. Como os homens iam para os campos de batalha, as mulheres se viram obrigadas a procurar emprego para que pudessem sustentar suas famílias, atitude essa seguida também pelas mulheres solteiras (ESPÍNOLA, E. 2001).

A edição da Constituição Federal de 1988 trouxe princípios que devem permear a convivência familiar, de tal forma que ela deixe de ser valorada como instituição e exerça a função de responsável pela personalidade e dignidade de seus membros, como deseja o texto constitucional. Dessa forma, a família é protegida não pelo que ela representa em si mesma, mas sim como meio de realização dos indivíduos (TEPEDINO, G. 1999).

Neste sentido, Gustavo Tepedino explica que:

\begin{abstract}
Assim sendo, a família, embora tenha ampliado, com a Carta de 1988, o seu prestígio constitucional, deixa de ter valor intrínseco, como instituição capaz de merecer tutela jurídica pelo simples fato de existir, passando a ser valorada de maneira instrumental, tutelada na medida em que - e somente na exata medida em que - se constitua em um núcleo intermediário de desenvolvimento da personalidade dos filhos e de promoção da dignidade dos seus integrantes. (TEPEDINO, 1999, p.350)
\end{abstract}

Diante do exposto, verifica-se que a família evoluiu em direção à valorização do companheirismo e afetividade em detrimento dos aspectos patrimoniais, como requisitos de uma família bem estruturada. Assim, os preceitos constitucionais garantem proteção justamente a essa família que preza pela dignidade e realização da personalidade de seus membros.

\title{
2.2 Novas perspectivas do conceito de família
}

A família é uma instituição que se mantém em meio a todas as transformações por que passa a humanidade, adequando suas estruturas a cada época e fiel à sua função de formar o sujeito e transmitir a cultura (MOTTA, M. A. P. In PEREIRA, R. C. 2000).

É notável como a família vem se modificando ao longo dos anos, entretanto, fatos importantes como o início do fluxo de pessoas dos campos para os centros 
urbanos, a inclusão das mulheres nos meios de produção, entre outros, contribuíram sobremaneira para que a família se distanciasse do modelo clássico em direção a sua evolução (FIUZA, C. A. C. In PEREIRA, R. C. 2000).

Antes da Constituição de 1988, as demais, excluída a de 1967, por afirmarem que o casamento civil era indissolúvel, acabaram dividindo as famílias em legítima e ilegítima. A legítima era constituída através do casamento civil e tinha total amparo constitucional, a ilegítima era formada sem conformidade com a lei e, portanto, não tinha proteção legal. O Código Civil de 1916 definiu como legítima a família formada pelo casamento civil, desconhecendo o concubinato, pois esse era visto como inferior ao casamento e cercado de preconceito por parte da sociedade (PEREIRA, R. C. 2000).

A dissolução do casamento lentamente foi sendo aceita, tendo como marco inicial a Lei do Divórcio $\mathrm{n}^{0}$ 6.515/77, no momento em que se nota que o conservadorismo do Código Civil de 1916 não conseguia acompanhar a evolução da sociedade. A igreja não aceitou a nova Lei e, como forma de protesto, proibiu o casamento religioso dos divorciados, levando, portanto, os casais a viverem como concubinos. O cristianismo católico não reconhecia os filhos havidos de pais não casados, pregando que eram frutos do pecado sexual. Para que o filho fosse considerado legítimo, os pais deveriam se casar na igreja. Contudo, ainda era maior a discriminação sofrida pelos filhos adulterinos e incestuosos, que além de serem considerados um pecado, feriam a moral e os bons costumes da sociedade.

A Constituição de 1988 cessa a exigência do casamento como requisito para legitimar a família. O Estado começa a se preocupar com os direitos garantidos à família e não mais com as meras formalidades do casamento, proibindo a discriminação entre os filhos, tanto de natureza pessoal como patrimonial, colocando fim a uma história marcada pela distinção da filiação. O Estado, atualmente, protege toda família fruto da vontade de um casal, sem que para isso estejam obrigados a se casarem. O casamento ainda existe e é um ato formal, entretanto, não se caracteriza mais como essencial para que se reconheçam os direitos de uma família (PEREIRA, R. C. 2000).

Houve tempos em que não existia qualquer direito entre os companheiros, pois não estavam unidos pelos laços matrimoniais. Há algum tempo a união deixou de ser vista com maus olhos, possuindo atualmente proteção jurídica que lhe garante direitos antes nunca imaginados (CRISPINO, N. E. B. In PEREIRA, R. C. 2000). 
Atualmente um casal não se casa por conveniência ou para poder formar uma família, hoje eles estão mais interessados em criar uma vida em comum, visando o companheirismo. Nos tempos mais remotos os indivíduos não se casavam com a intenção de compartilharem idéias, projetos de vida, mesmo porque a mulher exercia um papel inferior ao exercido pelo homem. Hoje as mulheres também querem mandar, atuarem de forma visível na sociedade e não permanecerem escondidas em casa obedecendo às ordens do marido. Elas trabalham e ajudam no sustento do lar. Assim, nos dias atuais, cada pessoa é livre para escolher o caminho a seguir, a profissão a escolher e o que resta ao casal é se adequar e apoiar as escolhas do outro e, a troca de boas experiências entre ambos é que faz que a união perdure (RIBEIRO, R. J. In PEREIRA, R. C. 2000).

A separação passou a ser corriqueira, pois os casais se acostumaram com a rotina e evitam buscar a renovação do casamento a cada dia. A manutenção da união, por não ser obrigatória, apenas sobrevive se for interessante para o casal. As famílias estão empenhadas em buscar acima de tudo a felicidade e para isso precisam agir com cuidado, delicadeza, prudência, para que não se desestruturem. Dessa forma, o marido deixa de ser visto como superior à mulher, sendo, agora, ambos tratados com igualdade. O casamento deixa de ser apenas meio de procriação, tornando-se uma relação de cumplicidade (FACHIN, L. E. 1992).

A Constituição de 1988 traz como um de seus fundamentos o respeito à dignidade da pessoa humana, valorizando a individualidade, reconhecendo assim as diferenças de cada indivíduo. A existência da família e do casamento é condicionada ao desenvolvimento da pessoa, respeitando os interesses individuais, preocupando-se, sobretudo, com a formação da personalidade de seus membros. Os vínculos patrimoniais e sanguíneos anteriormente essenciais para a família, hoje aparecem em segundo plano, visto ter o vínculo afetivo maior importância. Nesse contexto, Jacqueline Filgueras Nogueira, citando Luiz Edson Fachin explica que: "sob a concepção eudemonista de família, não é o indivíduo que existe para a família e para o casamento, mas a família e o casamento existem para seu desenvolvimento pessoal, em busca de sua aspiração à felicidade” (NOGUEIRA, J. F. 2001).

Os princípios que norteiam a família são: liberdade e igualdade, donde se verifica que a liberdade pressupõe a afetividade e a igualdade determina a inexistência de hierarquia entre os membros, caracterizando a família como uma sociedade democrática, sustentada pela compreensão e pelo amor. A família preza pela 
cumplicidade e cada um de seus membros procura dentro dela sua própria realização, seu contentamento e bem-estar. Assim, a família não mais se caracteriza como a patriarcal do modelo antigo, redesenhando seu modelo, com uma dimensão renovada, voltada para a igualdade e à direção diárquica, a não discriminação (FACHIN, L. E. 2006).

A Constituição de 1988 caracteriza-se como a precursora da evolução da família, ao amparar legalmente a união entre um homem e uma mulher, que antes não era admitida por não seguir as regras formais de um casamento. Garantiu também que os filhos havidos de qualquer relação, possam ser reconhecidos em igualdade de condições, proibindo qualquer tipo de discriminação entre eles. Por fim, a sociedade patriarcal desaparece fazendo surgir a igualdade entre o homem e a mulher, permitindo que o poder familiar seja exercido em conjunto (RIBEIRO, S. C. C. 2005).

\subsection{Mudanças na relação familiar: mulher nas transformações sociais}

Apesar dos direitos constitucionalmente garantidos, a subjugação feminina ultrapassa as barreiras do tempo, sendo ainda identificável na sociedade. Há alguns séculos atrás o papel da mulher se limitava ao ambiente familiar, hoje, após reivindicarem a igualdade entre os sexos, foi-lhes garantida maior participação, porém, a discriminação persiste mesmo que camuflada e em menores proporções.

Desde o início da civilização os homens buscaram justificar a discriminação às mulheres. Inicialmente apoiavam-se na justificativa física para lhes reservar atividades limitadas e vida abrigada. A tradição Cristã pregava que as mulheres deveriam se resguardar no ambiente familiar, observando a maneira como se vestiam para que não ficassem expostas, desencaminhando os homens.

A transformação da sociedade ocasionada pela urbanização do século XIX agravou a discriminação das mulheres. Elas passaram a desempenhar papéis exclusivos de reprodutoras e donas de casa, reforçados por médicos que afirmavam a existência de limitações físicas que as acometiam, impedindo o exercício de funções mais complexas.

Durante longo período, as mulheres foram proibidas de trabalharem fora de seus lares. Entretanto, as atividades exercidas dentro do lar não eram reconhecidas como as que visavam à troca de serviços ou remuneração e, até mesmo o camponês que trabalhava por conta própria, era reconhecido como o verdadeiro trabalhador em detrimento da mulher. A mulher não dispunha de autonomia, era submetida às ordens dadas pelo marido mesmo no exercício de suas funções domésticas. 
As atividades exercidas pelas mulheres não eram vistas em sua importância. Apesar de indispensáveis para a sociedade, o trabalho feminino não possuía prestígio algum. Nota-se que, épocas se passaram sem que a mulher fosse reconhecida pelas atividades que desempenhava e menos ainda pelas contribuições dadas à formação da sociedade. As mulheres muito trabalharam, mas a verdadeira consideração social não lhes foi dada, elas não conquistaram riquezas, direitos e independência.

A industrialização vivida no decorrer do século XIX modificou o cotidiano da vida na sociedade, bem como as funções e ocupações sociais das mulheres. Contudo, tais transformações não terminaram com as restrições legais, atitudes repressivas e exclusões sofridas pelas mulheres, em uma sociedade marcada pelo predomínio patriarcal. E, ainda, os estudiosos da época nada falavam sobre essa situação, que ficava limitada a literatura médica e jurídica que estabeleciam a maneira como as mulheres deveriam se portar, tendo por base as expectativas tradicionais.

O crescimento da população fez surgir novas relações de emprego e acirrar a competição por um posto no mercado de trabalho. Mesmo com as transformações ocorridas a tradição cultural reforçava a idéia de imoralidade no trabalho desempenhado pela mulher fora do lar. Como a mulher era vista na sua fragilidade o lugar considerado como seguro para estar era o lar, exercendo o papel de esposa. A mulher casada era vista em sua virtuosidade, enquanto prevalecia sobre as solteiras, as quais não viviam exclusivamente para a família, certo estigma.

A natureza feminina foi classificada no decorrer dos anos de forma que as colocasse em posição de inferioridade na sociedade. Assim, as sociedades patriarcais ditavam o comportamento feminino tendo como base o modo de agir masculino. Aos homens eram garantidos privilégios comportamentais que se fossem desempenhados pelas mulheres denotariam uma violação na ordem social. Tal ordem que definia papéis e deveres de todos era, praticamente, uma ordem social sem explicações fisiológicas constantes e irrecusáveis. Porém, era imposta e seguida como se configurasse a própria ordem da natureza e, sempre obedecida como sagrada e intocável. O comportamento compatível com a ordem imposta demonstrava o medo de gerar uma confusão no seio da sociedade, permitindo a aplicação de sanções morais e sociais para retornar ao estabelecido previamente.

O casamento, tido como a chave para a adequada inclusão social, era sagrado e por esse motivo o divórcio foi entendido como algo imoral, sendo condenado durante um longo período. Ressalte-se que, apesar do reconhecimento de alguns 
casamentos como discriminatórios às mulheres, o divórcio não era permitido vez que configurava a vontade de emancipação feminina e não uma forma de proteção das mulheres contra seus maridos.

A tomada de consciência da situação de marginalização feminina desencadeou as primeiras iniciativas na busca por direitos até então negados. Tal luta avançou a passos lentos, sendo que na década de 20 e 30 do século XX, foi apresentado um debate sobre o papel da mulher na sociedade. Porém, mesmo os grupos intitulados feministas não reivindicavam amplamente as injustiças sociais vividas, bem como deixavam de lado as mulheres provenientes das camadas de baixa renda e desconsideravam o problema da prostituição.

O feminismo, mesmo não tendo lutado amplamente contra as justiças sociais desde o seu surgimento, englobou um intenso processo que culminou nas transformações da vida tradicional, libertando as mulheres do confinamento do ambiente doméstico. Segundo Costa (1992), assim como o Marxismo construiu uma teoria inclusiva sobre a transformação da sociedade tendo por base a luta de classes, a teoria feminista colocou a opressão da mulher no centro de suas formulações, dando-lhe um estatuto teórico equivalente ao da exploração de classe.

No decorrer dos anos, agüentando as pressões geradas pelo preconceito, as mulheres foram ocupando seu espaço fora do lar, seja pela necessidade de sobrevivência ou interesse pessoal. Entretanto, as divisões de tarefas continuaram sendo determinadas em razão do gênero, o que explica a ausência dos homens no desempenho de tarefas domésticas mesmo quando o tempo gasto no trabalho fosse idêntico. Observa-se também, que o número de mulheres chefes de família cresce, dando mais visibilidade a diferença de gênero, em que a pobreza é maior quando comparada aos lares chefiados por homens.

Importante definir o conceito de gênero como sendo uma definição sociológica, necessária para a diferenciação entre o sexo biológico de sua tradução social em papéis sociais e expectativas de comportamentos femininos e masculinos, tradução esta assinalada por relações tradicionais de submissão feminina. O gênero é uma formulação social aprendida e transmitida no decorrer dos anos e contém a noção de que o poder é garantido de forma desigual entre os sexos, restando às mulheres posições inferiores na organização da vida social.

Vítimas da rotulação baseada no gênero, as mulheres se vêem como as maiores prejudicadas pela violência doméstica. Isso porque, dados comparativos 
demonstram que os homens se envolvem com maior freqüência em violência com um estranho enquanto as mulheres são mais prejudicadas por conflitos ocorridos dentro do ambiente doméstico. Nota-se, por outro lado, que os homens no processo de socialização entram em contato com a violência desde cedo, justificando a maior aceitação de atos violentos praticados por estes.

A diversidade assusta aos seres humanos, porém, não mais que uma reflexão sobre os motivos de tais diferenças. Assim, por exemplo, as justificações segregacionistas são formuladas à base de argumentos de natureza. Saber que o outro é diferente é mais aceitável que pensar no outro como igual, assim, pensar em homens brancos e negros como semelhantes é uma proposta que assusta. As classificações estabelecidas pelas sociedades consistem em distinções, classificações, realização de pesquisas das origens das diferenças, usualmente para legitimá-las e as reforçar.

Grandes personalidades podem aceitar o fim das diferenças entre os seres, porém, para a maioria da população isso significaria uma ameaça de autodestruição. Tem-se que a personalidade individual determina uma maneira de viver, as características próprias de branco perante o negro, de mulher perante o homem, por exemplo. Geralmente, os indivíduos desejam que os seus semelhantes lhes proporcionem seus próprios comportamentos, o que lhes disponibiliza uma diversidade de situações e de vida padrão que os rotula conforme a obediência às normas daquele grupo.

Os sinais que caracterizam o gênero são específicos da comunidade. Ao contrário dos animais, os humanos não padronizam seus comportamentos se levado em consideração a espécie, pois nos humanos o conformismo vincula-se à sociedade, aos costumes, as leis. As distinções na eleição de tarefas como sendo masculinas ou femininas fazem parte da história das sociedades, visto ainda não se ter relatos de locais onde não se estabeleceram sinais artificiais para tais diferenciações.

O senso comum compreende erroneamente que a diferenciação entre os papéis masculinos e femininos devem-se a fenômenos naturais e que, portanto, precisam ser aceitos. A refutação de tal ordem apresenta-se como um problema desnecessariamente colocado na sociedade, pois não se deseja vislumbrar um lugar onde o interesse pelas vocações do sexo oposto fira a ordem e crie a angústia de um mundo desorganizado.

É notável que as justificativas naturais são utilizadas como explicação para que a ocupação feminina seja inferior e o masculino atue com superioridade. Assim, o 
trabalho desempenhado pelas mulheres historicamente foi visto com descrédito, atribuindo-lhes piores salários, menor reconhecimento quando comparado ao garantido aos homens durante o mesmo momento histórico, os quais nada tinham de maior utilidade para a vida humana e social. As tarefas femininas, basicamente manuais durante a antiguidade, são vistas como desprovidas de um livre arbítrio, de habilidade inteligente e possibilidade de aperfeiçoamento. Ressalte-se que, o trabalho manual naquela época era considerado como uma função estranha à pura essência masculina e uma necessidade inferior ao homem.

A permanência no mercado de trabalho demonstra que as mulheres geralmente se afastam devido a fatores conjunturais e familiares. Porém, os filhos são os principais fatores na demonstração da participação feminina no mercado de trabalho. A necessidade de cuidar e educar os filhos e a precariedade dos instrumentos coletivos, como as creches, afastam as mulheres do mercado, principalmente se a remuneração for incapaz de cobrir todas as despesas adquiridas com as crianças. Entretanto, quando se trata de famílias muito pobres ou chefiadas por mulheres, há necessidade de recorrer à ajuda familiar ou mesmo dos vizinhos para que fiquem com a criança enquanto a mãe trabalha. A difícil conciliação se agrava pela precarização do trabalho, em que o trabalho informal, sem horário fixo, distante do domicilio da trabalhadora e sem garantias trabalhistas, dificultam o desempenho das responsabilidades familiares e atividades econômicas.

Desempenhar o papel de mãe e trabalhadora é uma tarefa árdua especialmente quando se tem filhos pequenos, visto necessitarem de maiores cuidados e existirem políticas sociais ineficazes, sobretudo para atendimento de famílias pobres. Assim, devido a estes problemas, a escolaridade feminina e a inserção da mulher no mercado estão profundamente ligadas. As mulheres com maior escolaridade são mais requisitadas, tendo melhor remuneração que lhes permitem suprir sua saída do lar.

Por outro lado, tendo o tema da violência como referência, nota-se que no Brasil a violência contra a mulher é decorrência da organização social de gênero. Dessa forma, a tendência da população é considerar que a violência sexual cometida pelo companheiro não pode ser classificada como um ato violento, vez que não foi praticado por um estranho, constituindo assim um dever conjugal. As transformações sociais impuseram a real compreensão dos direitos femininos, por parte de algumas mulheres, as quais já não aceitam a violação sexual dentro do casamento, demonstrando ao companheiro que tal relação pressupõe um acordo de vontades. Contudo, grande parte 
dos homens ainda se vêem como superiores às mulheres e certos da impunidade, cometem violência contra suas companheiras.

Certos fatos demonstram a recusa feminina de subordinação ao homem, tendo essa muitas vezes a resposta em forma de violência com conseqüências imprevisíveis. Com o passar dos anos grande número de mulheres foram adquirindo maior consciência de sua cidadania superando a noção masculina, trazendo para a sociedade um caráter de instabilidade própria de processos de transição. Aqui é importante frisar que essa nova atitude de algumas mulheres não configura a razão da violência, mas sim um elemento desencadeador.

O gênero feminino não se mostra internamente homogêneo. Uma parte das mulheres se empenha para por fim à relação de dominação, reivindicando seus direitos. Dentre estas, algumas se concentram na luta pela ampla cidadania feminina, fazendo uma relação entre direitos humanos a partir do gênero. Tais envolvimentos na causa feminina geralmente influenciam na criação de políticas públicas compensatórias para o combate à discriminação contra a mulher. 


\section{CAPÍTULO III}

\section{DELEGACIAS DE DEFESA DA MULHER (DEAM)}

Criadas em 1986, em São Paulo, as Delegacias de Defesa da Mulher representaram um inusitado avanço para o Brasil, sendo posteriormente inauguradas em outros estados do país e também em outros países da América Latina. No Brasil, a criação de tais delegacias apenas foi possível devido ao contexto democrático vivido nos anos 80 e pela pressão dos movimentos feministas que insistiram na demonstração da falta de interesse pela violência contra a mulher, por parte do sistema judiciário.

As delegacias da mulher representaram um posicionamento do Estado frente à reivindicação pelo fim do machismo que marcava a atuação da polícia e aplicação das leis brasileiras, transformando-se assim na principal política pública de combate à violência contra as mulheres. Porém, não se quer aqui afirmar que o surgimento de tais delegacias conduziu à diminuição das agressões a cada registro de ocorrência, mas mostrar que elas deram evidência a necessidade de ação da sociedade para requerer políticas públicas específicas.

Questões antes tidas como particulares passaram a ser levados ao conhecimento de autoridades por meio das delegacias da mulher, demonstrando a politização da justiça no tratamento dos direitos da mulher. Em 1996, por meio de decreto, as delegacias da mulher passaram a tratar casos envolvendo criança e adolescente em conflitos familiares. Visando agilidade na resolução de tais questões, a Lei 9099 criou os Juizados Especiais Criminais, o que foi objeto de crítica por parte do movimento feminista, resultando na criação dos Juizados Especiais Criminais da Família em São Paulo. Tais fatos demonstram a tentativa de reformular as funções das delegacias da mulher, voltando-as para o atendimento à violência familiar e doméstica.

Dessa forma, necessário se faz repensar na responsabilização da família como garantidora de uma sociedade mais equilibrada, como querem movimentos políticos que se intitulam progressistas e defensores dos direitos humanos, vez que a questão se remete a desigualdades de gênero, justiça e democracia.

Para a compreensão das delegacias da mulher deve-se atentar para três condições. Primeiramente a existência da democracia e a garantia dos direitos sociais no Brasil tendo na justiça o campo para a sua efetiva concretização. A polícia freqüentemente é exposta nos meios de comunicação, implantando o sentimento de ineficiência de seus agentes e delimitando a posição de subalternidade dessa instituição 
perante o judiciário. Em meio a esse dilema é que as delegacias especiais precisam ser entendidas permitindo o estudo das particularidades do sistema judiciário.

Em segundo lugar aparece a forma como universalidade e particularidade se relacionam no Brasil, possibilitando a criação de delegacias especiais reivindicadas por organizações governamentais e sociedade civil para atender grupos historicamente discriminados. Essas instituições são voltadas para a conquista da universalidade de direitos por meio do respeito à particularidade de opressão que cada grupo desprivilegiado sofre. Dessa forma, os agentes encontram desafios para conciliar ética profissional com a defesa dos interesses das minorias, o que exige grande criatividade para lidar com os casos atendidos.

Por fim, como conseqüência do segundo pressuposto para compreensão das delegacias especiais, está a chamada “judicialização das relações sociais” a qual representa a crescente intromissão do judiciário na formação da vida social. Nas sociedades contemporâneas tal invasão não se restringe ao meio político, mas alcança esferas tradicionalmente privadas. Contudo, as delegacias especiais podem ser entendidas de modo diverso, sinalizando um avanço traduzindo em direitos os interesses de grupos sujeitos ao estatuto da dependência pessoal.

Os dilemas enfrentados por referidas delegacias interferem diretamente na construção do crime de violência doméstica. Esse tipo de crime requer um tratamento diferenciado do que é dispensado a outras formas de violência, pois vítimas e acusados são tratados como cidadãos incapazes de exercer direitos civis. As justificativas para a ocorrência do crime de violência doméstica remetem ao caráter moral ou conseqüência da incapacidade dos membros da família em se responsabilizarem pelos diversos papéis que cada etapa da vida familiar exige. Os agentes analisam a família como uma instância causadora da violência, em que os deveres de cada membro necessitam ser delimitados, sendo as instituições de justiça responsáveis pela criação de mecanismos para reforçar o desempenho de seus respectivos papéis.

Com o reconhecimento de tais constatações é que se pode perceber a importância de uma seção dentro das delegacias especializadas para o acompanhamento de indivíduos que se apresentam como incapazes de manterem relacionamentos familiares saudáveis. Como exemplo bem sucedido, temos o município de São Carlos, onde a delegacia da mulher ganhou reconhecimento e prestígio por prestar atendimento psicológico às vítimas de violência doméstica por meio de um convênio firmado com o Departamento de Psicologia da Universidade Federal. Após serem estabelecidos os 
atendimentos dentro da delegacia, constatou-se que a maioria das demandas era para o acompanhamento psicológico e não o policial.

Nas delegacias da mulher é possível constatar a forma diferenciada de motivação entre as vítimas de violência doméstica, levando-se em conta o nível socioeconômico. Mulheres de classes baixas geralmente se encontram em relação de dependência do marido e buscam a delegacia como único meio para uma solução imediata do problema, saindo frustradas porque isso não é possível. Por outro lado, as mulheres de classes mais altas geralmente dispõem de outros recursos, são mais instruídas e independentes financeiramente, apenas buscando a delegacia para formalizar um ato que servirá como prova em um processo de separação. Portanto, elas têm em mente que a solução de seus problemas não se encontra em um boletim de ocorrência.

É notável que a procura pela polícia, nas camadas mais populares, seja um recurso visto como mais eficiente para pressionar o agressor a ajustar seu comportamento, dando à autoridade policial o papel de educadores de homens acusados de agressão. Grande parte dos casos poderiam ser resolvidos entre o casal, desde que o diálogo fosse realmente possível. Porém, muitas vezes o que se pode observar é a procura pela autoridade para um simples desabafo, como meio de orientação ou uma forma de assustar o agressor. Para a população mais pobre, a polícia é vista como um meio para o conhecimento da lei e uma forma de conseguir respaldo institucional para a solução de conflitos familiares.

Dessa forma, o trabalho dos agentes acaba se desvirtuando para uma função mais de assistente social que propriamente policial, na medida em que as vítimas desejam a resolução de problemas sociais e não a punição dos culpados. Treinados para outro tipo de atividade, os agentes se vêem tendo que fazer a conciliação do casal em conflito, o que causa uma monotonia no cotidiano da delegacia.

De forma cada vez mais corriqueira, as estatísticas vem demonstrando que o ambiente familiar não pode mais ser considerado como o espaço de harmonia, mas, como se tem constatado, como um lugar em que ocorrem relações de opressão, abuso físico, emocional e ausência de direitos individuais. Baseados nessas constatações, autores afirmam com razão que é dentro do próprio lar que a mulher e a criança correm mais risco e, para as mulheres, a família é vista como um grupo perigoso.

Segundo demonstra Cláudia Fonseca, os agentes das delegacias da mulher assim pensam: 
Consideramos, por exemplo, a recomendação das feministas de que, nas Delegacias da Mulher, o atendimento se distancie da "lógica da queixa”, isto é, que o atendimento vá além da escuta e consolo, além da “demanda imediata, com todo o caldo cultural e estigmatizante que pode estar em jogo”, almejando um efeito amplo, profundo e duradouro na promoção dos direitos fundamentais da mulher. [...] Ao limitar o escopo da intervenção à demanda do dia-a-dia, “apagando fogos”, os agentes correm o perigo de esvaziar o potencial transformador das Delegacias. Arriscam produzir um efeito meramente paliativo, fornecendo um tipo de válvula de escape para as tensões num sistema de relações de gênero profundamente desiguais. (DEBERT; GREGORI; PISCITELLI, 2006, p.176)

A vida de uma mulher baseada em suas relações, sobretudo familiares, não pressupõe que ela obedece cegamente às regras de uma sociedade patriarcal. Atualmente a mulher se vê em uma gama de relacionamentos que não se reduzem ao papel de companheira. Nesse meio social a mulher percebe diversas justificações para confrontar a autoridade do marido, demonstrando que também possui direitos que devem ser respeitados. Dessa forma, é necessário que os agentes sociais lotados nas delegacias da mulher reconheçam a personalidade complexa de seus usuários e se empenhem em estabelecer os diversos valores em questão.

Tem-se que as construções historicamente culturais determinaram quais seriam os papéis desempenhados por homens e mulheres. A violência contra a mulher deve ser encaixada nesta construção sócio-cultural hierarquizadora e desigual e não como um problema a ser resolvido entre o casal. Assim, dentre as reivindicações do movimento feminista estaria a luta pela redistribuição do poder, absolutamente mais igualitário. Por meio de discussões feitas sobre o tema violência doméstica, elas colocaram em evidência um conjunto de medidas para a intervenção no fenômeno, aqui se estabelecendo a criação de delegacias especiais.

Ainda que as dificuldades enfrentadas no funcionamento das delegacias especiais persistam, não se pode ignorar o fato de que elas constituem a principal política pública de prevenção e combate à violência contra as mulheres. Permitiram a reserva de locais específicos para a denúncia da violência contra as mulheres e se caracterizaram em meios de divulgação do fenômeno.

Quando o movimento feminista deu início a suas reivindicações pela criação de delegacias especiais, o argumento contrário era de que estas eram desnecessárias. Diziam que a demanda em tais delegacias seria irrisória para justificar a implementação 
da proposta. Contudo, os dados foram favoráveis aos pedidos das militantes. O movimento deu conhecimento à questão da violência contra a mulher, gerando o encontro entre duas esferas: público e privado, demonstrando que as relações conjugais eram construídas em desvantagem para a mulher. Dessa forma, trouxe ao conhecimento público a violência sofrida dentro do ambiente íntimo, tido como meio protegido de todo tipo de perversidade.

Desde os anos 80, no Brasil, a ação do Estado restringiu-se basicamente à proteção policial e ao encaminhamento jurídico dos casos, visando à punição do agressor e reparação da vítima. As avaliações em torno desta política apontaram este como um aspecto de insuficiência para uma intervenção de impacto sobre o problema. O isolamento das delegacias da mulher reduziu o impacto desta ação e, difundiu uma percepção de que as vítimas desistiam de seu objetivo inicial ao apresentarem a denúncia. Porém, constata-se que os agentes discordam desta afirmação, conforme entrevista concedida na delegacia da mulher em Brasília, vez que defendem sua ação profissional como sendo uma investigação criminal e, ainda, informaram que a mulher vítima de agressão pode procurar a delegacia mais próxima, pois todas possuem uma seção para atendimento específico.

Portanto, conforme já citado acima, algumas informações foram colhidas na delegacia da mulher localizada em Brasília(anexo I). A entrevista foi realizada com uma agente da delegacia, a qual possui formação em psicologia, tendo informado que na instituição não existe nenhum tipo de orientação psicológica, apenas informalmente quando é o caso de ajudar a vítima a se acalmar, exercendo tal profissional a função de agente de polícia. Assim, quando se recorre à delegacia será realizada uma orientação para se verificar a ocorrência de crime ou não. Se não houver crime orienta-se a procura de outro profissional, caso contrário haverá o registro o que gera a investigação policial. Se for o caso de denúncia anônima, os agentes se deslocam para o local onde foi citado pelo informante.

Atualmente, referida delegacia contabiliza trinta e sete denúncias anônimas, em sua maioria fora de Brasília. A polícia vai até o local para demonstrar ao autor que eles estão acompanhando o caso mesmo sem a existência de uma denúncia formal.

Fica a impressão de que as delegacias da mulher são discriminadas, o que na prática realmente ocorre, tendo como causa, segundo a agente entrevistada, as chefias das seções serem presididas em sua maioria por homens, muitos deles com comportamentos machistas. Outro dado que revela a discriminação das delegacias da 
mulher é a recente desconstrução da cultura de que não se deve intrometer na briga de marido e mulher.

Alguns autores afirmam que a procura nas delegacias ocorre mais por mulheres das camadas populares, assim como foi relatado no presente estudo, elas buscam uma solução imediata para seus problemas e vêem na instituição a única saída. Elas vão à delegacia não atrás de uma clareza de que há um propósito de punir, mas se reivindica a intervenção de uma autoridade que possa regular as relações domésticas. Depositou-se nas delegacias da mulher a expectativa de oferecerem a resposta global no enfrentamento ao problema da violência doméstica. Na prática o que se percebe é a busca vinda de todas as classes, porém as classes mais altas possuem outros meios para se livrarem da situação de violência.

Verifica-se que na maioria dos casos ocorre a revitimização, o que é visto na experiência como uma dependência psicológica justificada pela inserção secundária das mulheres na sociedade. A violência ocorrida no próprio lar é uma questão complexa que envolve afetividade. A repetição da agressão é um ciclo de uma relação doentia, que traz conseqüências na auto-estima da vítima, minando-a até que ela se encontre em um estado de dependência por questões financeiras ou emocionais. Contudo, a principal categoria que envolve a questão é o gênero, o que gera a submissão feminina. Problemas com álcool, drogas, por exemplo, são apenas potencializadores da agressão, tudo que envolve a relação conjugal doentia passa antes pela questão de gênero.

Quando as vítimas chegam à delegacia elas recebem um formulário para preenchimento, no qual devem indicar inclusive a medida protetiva que desejam. Geralmente a determinação é para que o agressor não freqüente determinados lugares e se afaste do lar. A Casa Abrigo é uma instituição para onde as vítimas são encaminhadas pela delegacia da mulher, podendo ir acompanhadas de seus filhos. Apesar de ser um ambiente eficaz para a proteção das vítimas, porque seu endereço é mantido em sigilo, reclama-se da precariedade do local e da falta de um número de casas que atenda a quantidade de demanda. Ressalte-se que, mesmo com o avanço na criação de seções dentro das delegacias, o encaminhamento para a Casa Abrigo é centralizado na delegacia da mulher.

É notável que, nos ciclos agressivos em algum momento o companheiro pede desculpa e a mulher perdoa, porque há relação afetiva, diferente de um estranho agressor. O fenômeno se caracteriza como uma doença social, sendo objetivo do Estado a ressocialização do agressor, o qual é visto como um ser educado em uma cultura 
machista que lhe leva a subjugar o sexo feminino. Quando os casos chegam ao judiciário, o Juiz orienta a procura por um tratamento ao agressor, até mesmo em programas de orientação podendo ser feito em conjunto pelo casal.

Portanto, o desafio está em combinar o atendimento policial com outras áreas, entre elas, o atendimento psicológico e o trabalho de assistentes sociais, visando à preservação da integridade da vítima. Isso porque, a violência doméstica modifica conceitos da própria criminologia, pois os indivíduos envolvidos são incapazes de exercer a cidadania devido à situação de dependência vivida. Tais fatos modificam o cotidiano das delegacias da mulher, dando a elas um caráter absolutamente próprio, na medida em que se voltam para a família como forma de restabelecer regras essenciais para o convívio entre pessoas ligadas por relações afetivas.

\subsection{0 sistema jurídico brasileiro de combate à violência doméstica}

Os crimes de violência doméstica cometidos no Brasil receberam tratamento singular durante um período considerável, sendo tipificados como crimes de lesão corporal e julgados nos Juizados Especiais Cíveis e Criminais, de acordo com a Lei 9099/95. Posteriormente com a Lei 10.886/04, ficou estabelecido o tipo da lesão corporal praticada contra familiares.

A Lei dos Juizados Especiais foi recebida com grande entusiasmo, pois trazia mudanças para os crimes considerados de menor potencial ofensivo, com pena máxima de dois anos. Tal novidade liberaria a justiça comum para o julgamento dos crimes mais graves. Por outro lado, significava um avanço, vez que permitia a aplicação de penas alternativas às penas de prisão.

Dessa forma, sob o advento de referida Lei, a mulher que era agredida mesmo que quase perdesse a vida teria o caso resolvido pelo Juizado Especial, que o considerava como de menor potencial ofensivo nos casos em que a vítima recuperasse a saúde, ficando o agressor sujeito a uma pena de seis meses a um ano ou multa, o que geralmente acabava em prestação de serviços à comunidade ou pagamento de cestas básicas. Os transtornos psicológicos decorrentes da agressão não eram levados em conta para a aplicação da pena, bem como o fato das agressões serem corriqueiras.

Apesar de não garantir o fim da violência doméstica ou contribuir com outras formas para preveni-la ou repreendê-la, a Lei dos Juizados Especiais possibilitou a divulgação desse crime, até então desconhecido pela sociedade. Ocorre que, os Juizados Especiais Criminais não foram pensados a partir de uma perspectiva de gênero, 
sendo criados sob o ideal masculino, pois surgidos para punir a conduta masculina delituosa de natureza eventual e não habitual, ou seja, de homens contra homens. Porém, os Juizados se surpreenderam com a quantidade de casos que chegavam para a resolução de agressões praticadas por maridos em desfavor de suas companheiras, ou seja, crimes praticados por homens contra mulheres.

Ao incluir a violência doméstica dentre os crimes de menor potencial ofensivo, o legislador desconheceu o verdadeiro valor da vida humana, permitindo conseqüentemente o desrespeito aos direitos fundamentais das mulheres. Assim, tal classificação configurou-se como uma enorme injustiça, vez que também foram ignoradas as implicações que decorrem da agressão, tais como: afetação emocional devido à habitualidade com que é praticada, o medo de colocar um fim na relação violenta, ameaça, a falta de liberdade, entre outras. Essa classificação também ignora o fato da progressividade da agressão, em que dados demonstram que grande parte dos homicídios cometidos contra as mulheres ocorrem devido à decisão de separação.

A falta de critério utilizado quando da classificação dos crimes de violência doméstica, ignorou o fato de ser este um problema que ocorre com habitualidade e envolve a vítima emocionalmente a ponto de paralisá-las. E, ao evitarem a busca pela solução do problema, acabam sendo vítimas de outros crimes relacionados, como por exemplo, o estupro. Portanto, a idéia de crime de menor potencial ofensivo não leva em consideração a evolução da violência e seu verdadeiro potencial ofensivo. Fica a impressão que referida classificação fundamenta-se pelo desejo de acobertar as agressões para que os homens continuem no poder e exerçam o controle sobre as mulheres.

Dessa forma, o crime de violência doméstica ficou efetivamente definido como crime somente com a Lei 10.886/04, a qual o acrescentou ao Código Penal como crimes cometidos no ambiente familiar. Porém, tal fato não foi totalmente positivo, porque se recusou em estabelecer um tipo autônomo para os crimes de violência doméstica, atrelando-os aos crimes de lesão corporal, com a vantagem de ser um crime qualificado.

Por outro lado, ficou estabelecida uma indenização pelos danos sofridos pela vítima, porém, como a maioria dos envolvidos é composta por pessoas desprovidas de recursos, tal garantia não alcança nenhum resultado positivo. Entretanto, as vítimas não se frustram pela falta de ressarcimento, visto que a procura pela justiça se justifica 
pela incapacidade de por fim à relação agressiva. Dessa forma, não se busca uma indenização e sim uma forma de acabar com a violência e garantir a segurança.

Outro aspecto trazido pela nova Lei era a enumeração de quais eram os sujeitos passivos do crime de violência doméstica, sendo eles: ascendente, descendente, irmão, cônjuge ou companheiro, ou com quem o agente conviva ou tenha convivido, ou, ainda, prevalecendo-se de relações domésticas de coabitação ou de hospitalidade. A pena cominada era de seis meses a um ano de detenção.

Apesar de não garantirem o fim da violência doméstica ou contribuírem com outras formas para preveni-la ou repreendê-la, as Leis acima citadas possibilitaram a divulgação das perversidades ocorridas nos lares, as quais permaneciam acobertadas pelo silêncio das vítimas e pelos membros da família.

\subsection{Lei Maria da Penha}

Após vários anos de luta contra a falta de atenção dada ao problema da violência doméstica, uma medida aparentemente eficaz foi adotada pelo sistema judiciário brasileiro. A brasileira que possibilitou a adoção de tal medida é Maria da Penha Maia Fernandes, a qual foi vítima das agressões de seu marido, o professor universitário Marco Antônio Heredia Viveiros. Em 1983 ele tentou assassiná-la, primeiramente com uma arma, deixando-a paraplégica e após por eletrochoque e afogamento, durante o banho.

Contudo, as agressões não ocorreram de repente. Durante o seu casamento, Maria da Penha foi agredida e intimidada constantemente, permanecendo em silêncio por medo de uma possível vingança contra ela e suas filhas. Após as duas tentativas de homicídio ela resolveu procurar uma solução para o caso, registrando a ocorrência na delegacia da mulher. Ocorre que, como o crime foi praticado em um momento regulado por Leis que não puniam o agressor de forma rígida, o marido apesar de condenado pela dupla tentativa de homicídio, conseguiu se manter em liberdade.

Foram dezoito anos de luta por justiça, até que em 2001 a Comissão Interamericana de Direitos Humanos da Organização dos Estados Americanos (OEA) acolheu as denúncias, feitas em 1998, pelo Centro para a Justiça e o Direito Internacional (CEJIL/Brasil) e pelo Comitê Latino-Americano e do Caribe para a Defesa dos Direitos da Mulher (CLADEM, seção nacional). A Comissão publicou o Relatório n54 responsabilizando o Estado Brasileiro por negligência e omissão em 
relação à violência doméstica, recomendando várias medidas no caso de Maria da Penha e a revisão das políticas públicas vigentes no âmbito da violência contra a mulher.

As conseqüências decorrentes das recomendações foram: a prisão de Marco Antônio Heredia Viveiros em 2002, por dois anos e, o que foi recebido com grande entusiasmo, a publicação da Lei 11.340/06, batizada pelo Presidente da República, Luiz Inácio Lula da Silva, como Lei Maria da Penha.

A Lei Maria da Penha representa uma grande conquista de todas as brasileiras. É a primeira Lei brasileira voltada para o atendimento das mulheres que sofreram violência doméstica e familiar e relaciona uma quantidade de preocupações com cada etapa do atendimento dos casos de violência, tanto nas delegacias, quanto perante o juiz ou promotor. Em cada uma das etapas, a Lei dispõe como deve ser o atendimento para garantir a segurança das mulheres agredidas e os direitos que lhes são assegurados para que possam superar a situação vivida.

A elaboração da Lei 11.340/06 objetivou a conceituação da violência doméstica e familiar como violação dos direitos humanos das mulheres e formulação de uma Lei que estabelecesse proteção e procedimentos judiciais e policiais humanizados para as vítimas. Assim, além de punir, a Lei conjuga aspectos conceituais e educativos, que a qualificam como uma legislação avançada e inovadora, capaz de tratar o conjunto de questões sociais e o crime de violência doméstica e familiar.

Apresenta-se, também, como finalidade da Lei a transformação dos valores até então admitidos pela sociedade, os quais não discriminavam a violência doméstica e reconheciam a superioridade masculina perante as mulheres. Dessa forma, as diversas formas de violência contra a mulher aparecem descritas na Lei como forma de conscientização nos meios: político, jurídico e social.

Desde sua promulgação, a Lei Maria da Penha tem sido alvo de questionamentos sobre a igualdade garantida pelo Estado entre homens e mulheres, argumentando que ela deveria alcançar ambos os sexos. Ocorre que, estatisticamente pode-se provar que as mulheres são as maiores vítimas de violência dentro de seus próprios lares.

Nesse sentido, a Pesquisa Ibope e o Instituto Patrícia Galvão apontam:

Uma em cada cinco brasileiras declara espontaneamente já ter sofrido algum tipo de violência por parte de um homem.

A cada 15 segundos uma mulher é espancada por um homem no Brasil. 
Um terço das mulheres (33\%) admite já ter sido vítima, em algum momento de sua vida, de alguma forma de violência física (24\% de ameaças com armas ao cerceamento do direito de ir e vir, $22 \%$ de agressões propriamente ditas e $13 \%$ de estupro conjugal ou abuso).

27\% sofreram violências psíquicas e 11\% afirmam já ter sofrido assédio sexual. Um pouco mais da metade das mulheres brasileiras declara nunca ter sofrido qualquer tipo de violência por parte de algum homem (57\%).

A responsabilidade do marido ou parceiro como principal agressor varia entre 53\% (ameaça à integridade física com armas) e 70\% (quebradeira) das ocorrências de violência em qualquer das modalidades investigadas, excetuando-se o assédio. Outros agressores comumente citados são o exmarido, o ex-companheiro e o ex-namorado, que somados ao marido ou parceiro constituem sólida maioria em todos os casos.

Aqui poderia ser citada, exaustivamente, uma infinidade de casos de agressões familiares contra mulheres. Porém, a título de ilustração, cabe apontar um caso ocorrido em Brasília:

No dia 2 de dezembro de 2005, João Xavier Ribeiro Filho, 50 anos, deu um tiro fatal no professor Elídio José Gonçalves e disparou mais cinco contra a estudante e sua ex-mulher Roseni Pereira de Miranda Ribeiro, 38 anos, no estacionamento de uma universidade em Brasília. O professor morreu e Roseni ficou com seqüelas nas cordas vocais. O advogado de João Xavier defendeu, em Júri Popular, que seu cliente agiu em legítima defesa da honra. O julgamento foi acompanhado por militantes do movimento de mulheres de Brasília. João Xavier foi condenado a 19 anos e 4 meses de reclusão. (CFEMEA, 2007, p.12)

As estatísticas refletem a relação de poder, da força física e da história de desigualdades culturais entre homens e mulheres, traduzidas em violência doméstica e familiar contra elas. Tem-se que essa forma de violência é baseada no gênero, caracterizando-se como similares e habituais, não importando a raça, classe social, idade ou orientação sexual, impedindo suas vítimas de exercerem seus direitos básicos.

As Leis brasileiras anteriores não tratavam a violência doméstica de acordo com a real gravidade deste crime, não garantindo proteção às vítimas e nem punindo o agressor da forma necessária. As agressões físicas e psicológicas contra a mulher eram definidas como lesão corporal leve, ameaça e injúria. Quando os casos chegavam à justiça, aconselhava-se que o casal se entendesse em nome da paz familiar. Como a maioria dos casos eram arquivados e, os que eram julgados recebiam como pena o pagamento de cesta básica ou a prestação de serviços comunitários, ficou implantado o sentimento de impunidade de tais crimes.

A Lei modifica alguns conceitos de família seguindo a evolução histórica da sociedade. Dessa forma, estabelece como família "a união de pessoas relacionadas de forma espontânea e afetivamente, sejam ou não aparentadas, vivam ou não sob o mesmo teto, hetero ou homossexuais”. 
As determinações dispostas na Lei colocam um fim no comportamento cultural de que as brigas conjugais devem ser resolvidas entre o casal e dentro de casa. Agora, a violência contra as mulheres configura-se como um problema de ordem pública, devendo o Estado, ao tomar conhecimento do fato, providenciar a medida cabível ao caso concreto. Dessa forma, o combate a violência não se restringe a estabelecer penas mais severas aos agressores, a Lei também traz medidas de assistência social e inclui nos currículos escolares informações básicas sobre o tema violência contra a mulher.

Fica previsto a faculdade de se criar Juizados de Violência Doméstica e Familiar contra a Mulher, o que seria muito importante vez que se configurariam como espaços reservados para esses casos específicos, garantindo atendimentos mais humanizados por parte do Juiz, Promotor e Defensor Público, capacitados exatamente para a resolução deste problema. Porém, enquanto não forem criados referidos Juizados os casos serão enviados para as Varas Criminais, sendo que as vítimas de violência doméstica terão prioridade no atendimento.

Os crimes de violência doméstica refletem um histórico de boletins de ocorrência que quase nunca chegavam até o Juiz, vez que as vítimas desistiam de prosseguir com as denúncias, conseqüentemente as delegacias e o poder judiciário deixaram de dar atenção a tais agressões. Entretanto, sabia-se que aquelas desistências ocorriam geralmente por dependência econômica e emocional do agressor, por medo de alguma vingança ou, ainda, por não desejarem o fim do relacionamento, mas apenas o término das agressões. Agora, retirar as denúncias não é tão simples, pois para isso será necessário uma audiência, presentes o Juiz e o Ministério Público.

Dentre as proteções previstas pela Lei Maria da Penha, para que a mulher encontre meios para por fim à relação de agressão, estão os programas oficiais e comunitários de acolhimento. Aqui estão relacionadas as Casas Abrigo, o Programa de Proteção a Vítimas e Testemunhas Ameaçadas, os Centros de Referências e outros criados nos Estados e municípios onde a mulher se encontra. Porém, para que a mulher não precise modificar sua rotina e de seus filhos, foi criada a medida de afastamento do agressor do lar para que ela possa permanecer nele.

Assim é possível afirmar que o combate à violência contra a mulher depende de um trabalho conjunto dos três poderes do Estado, dos movimentos sociais e das comunidades. Isso compreende a formação de uma Rede para a proteção das vítimas, tendo como suporte os programas oficiais acima citados. Dentre eles, cabe aqui 
destacar o Centro de Referência como responsável pelos encaminhamentos da Rede. Propulsor do processo de resgate da mulher como ser social, local de atendimento e acompanhamento psicológico e social à mulher em situação de violência, trabalha para a recuperação da auto-estima da vítima e luta para que ela se torne sujeito de seus próprios direitos.

Atualmente o agressor pode ser condenado a cumprir uma pena de prisão de até três anos e, se preencher alguns requisitos poderá ter a pena substituída por uma pena restritiva de direitos, tais como: prestação de serviços à comunidade, limitação de fim de semana. O Juiz pode ainda, determinar que o agressor freqüente programas de recuperação e reeducação com o intuito de por fim aos casos de reincidência e também para a prevenção da violência. Porém, é importante ressaltar que a imposição de pagamento de multa ou cesta básica como pena, fica proibida com a nova Lei e que, uma vez condenado, o agressor ficará com a "ficha suja”, portanto, com antecedentes criminais.

Outro aspecto importante trazido pela Lei é a especificação das formas de violência doméstica contra a mulher, como sendo: violência física, psicológica, sexual, patrimonial, moral. Dessa forma, traz uma grande inovação ao tipificar a violência psicológica, a qual não tem aparência, se camuflando por não deixar marcas no corpo de quem a sofre, mas que gera uma diminuição dos valores e auto-estima, sendo responsável, inclusive, por casos de suicídio. Essa forma de violência até então não tinha relevância e agora vai se compreendendo a importância de combatê-la, vez que é possível responsabilizá-la não apenas pelo mal causado à vítima e sim pelos males causados a todos os membros da família. Sabe-se que os filhos que crescem nesses ambientes conturbados tendem a repetir o comportamento agressivo na vida adulta, contribuindo com o ciclo de violências.

Além dos dispositivos trazidos pela Lei como verdadeiros avanços para a proteção às mulheres vítimas de violência doméstica, ela ainda determina que suas normas devem ser interpretadas tendo como base os fins sociais e as condições peculiares das vítimas de tais crimes. Tal orientação deveria ser dada em todos os diplomas legais, sendo aqui demonstrado que cada caso deve ser tratado em sua particularidade, exigindo dos operadores o desapego de uma atuação generalista e a análise da melhor solução aos casos que lhes são apresentados.

Diante do exposto, é possível notar que o enfrentamento da violência contra as mulheres finalmente passou a compor a agenda do governo brasileiro, sobretudo no 
biênio 2006-2007. A promulgação da Lei Maria da Penha, a obrigação de disponibilizar recursos financeiros para combater a violência doméstica, o Pacto Nacional pelo Enfrentamento da Violência contra as Mulheres, demonstram novas metas para a resolução da questão. É a transformação pela consolidação dos direitos das brasileiras.

Contudo, para que todas as medidas formuladas, bem como a Lei Maria da Penha sejam eficazes, antigos hábitos brasileiros deverão ser superados, fazendo com que os recursos destinados sejam realmente executados e que a cultura machista e patriarcal que discrimina as mulheres e contribui com a violência desapareça.

Dessa forma, são sentenças como a do Juiz Edilson Rumbelsperger Rodrigues que devem ser radicalmente modificadas. Tais sentenças são fruto de uma estrutura patriarcal e machista que enxerga as mulheres como indivíduos inferiores. Senão, vejamos:

Para tirar a Lei Maria da Penha do papel, mesmo mais de um ano após sua promulgação, ainda é preciso atuar fortemente junto ao Poder Judiciário e também ao Ministério Público e Defensoria Pública. O caso do juiz Edilson Rumbelsperger Rodrigues, de Sete Lagoas, que qualificou a legislação como um conjunto de regras diabólicas e, em várias sentenças, negou proteção a mulheres vítima de violência doméstica é exemplar. (CFEMEA, 2007, p.4)

Da mesma forma, apresenta-se como digna de crítica por impedir o progresso no combate à violência doméstica, a decisão do Superior Tribunal de Justiça que não reconheceu a aplicação da Lei Maria da Penha ao caso de agressão de exnamorado contra ex-namorada. Segundo a defensora pública Juliana Belloque:

\begin{abstract}
A sociedade e os operadores do Direito não podem se esquecer de que o propósito maior da Lei Maria da Penha é a prevenção e a repressão da violência contra a mulher, fruto da discriminação de gênero que impera nas relações de afeto e familiares”, declarou Juliana Belloque, defensora pública e doutora em processo penal pela USP, ao Informativo do Portal Violência contra a Mulher. "Nesse sentido, não vejo como positiva a decisão do STJ, afastando a incidência da lei em caso de violência praticada por ex-namorado dentro da hipótese concreta descrita, em que a violência foi decorrência do ciúme e do sentimento de posse do homem sobre a mulher, mesmo após o rompimento da relação afetiva, ou seja, trata-se justamente de caso em que aflora a discriminação sofrida pela mulher na sociedade, que a lei visa erradicar”, criticou a defensora pública.
\end{abstract}

Mais recentemente temos o caso de Eloá, 15 anos, assassinada por seu exnamorado. A imprensa de todo o país transmitiu o desfecho da história, focando nas ações do Grupo de Ações Táticas Especiais (GATE) e tratando o assassino como alguém que errou em nome de um amor doentio, escondendo o caso típico de violência 
de gênero. A vítima morreu porque se recusou a continuar aceitando uma relação contra sua vontade, mas da vontade do ex-namorado. Ela morreu por não aceitar uma relação de poder e dominação e por ser uma mulher que vive em uma cultura machista e patriarcal. Assim como Eloá, diversas são as vítimas cotidianamente maltratadas, agredidas para garantir que tudo continue como sempre foi, com as mulheres não questionando as vontades masculinas. Dessa forma, dados da Secretaria Especial de Políticas para as Mulheres da Presidência da República demonstram que 134 mulheres foram vítimas de cárcere privado, descobertas por meio de denúncias recebidas pela Central de Atendimento à Mulher (ligue 180).

Portanto, a divulgação da Lei Maria da Penha apresenta-se como uma medida urgente para garantir seu integral cumprimento, protegendo-a de possíveis meios para burlar os direitos das mulheres dispostos em seu texto. Disponibilizar o tema da violência contra as mulheres nas salas de aula, investir na divulgação da lei e em campanhas educativas são meios de modificar a história de injustiças praticadas contra as brasileiras até o presente momento é uma forma de fazer com que toda a sociedade reconheça que as mulheres têm direito ao poder, não sobre os homens, mas sobre elas mesmas. É necessário, ainda, capacitar o Executivo, o Judiciário, o Ministério Público e as Defensorias para as questões que envolvem gênero e direitos humanos. Neste contexto: “A Lei Maria da Penha, com todos os seus 46 artigos, só será realmente efetiva quando Estado e sociedade assumirem definitivamente o enfrentamento da violência doméstica como prioridade”. (CFEMEA, 2007, p.4)

\subsection{A experiência da Casa Abrigo}

O Programa Casa Abrigo de mulheres vítimas de violência é composto de ações multidisciplinares desenvolvido pelo Conselho dos Direitos da Mulher, órgão vinculado à Secretaria de Justiça Direitos Humanos e Cidadania. É um ambiente que garante a segurança e defesa à proteção de mulheres, crianças e adolescentes vítimas de violência doméstica e sexual.

O Programa além de objetivar a proteção das vítimas de violência, procura orientá-las para que vençam o medo e denunciem os seus agressores, vez que esse mecanismo é extremamente importante no combate à violência. Dessa forma, constituise em uma ação governamental de grande valor por colaborar sobretudo com o reconhecimento de cidadania esquecido com as agressões. 
Nossa metodologia de trabalho foi composta de entrevista com corpo técnico e mulheres abrigadas. A advogada da instituição explicou como funciona o programa. Importante ressaltar que é mantido em sigilo o endereço da Casa Abrigo, sendo que as visitas às abrigadas são feitas no Conselho. As mulheres chegam a Casa Abrigo por meio da Delegacia da Mulher, desde que registrem ocorrência e demonstrem interesse na medida. Demonstrado o interesse, os agentes as acompanham até o domicílio para que recolham seus pertences. Quanto às crianças e adolescentes vítimas de violência, ficam responsáveis pelo encaminhamento à Casa Abrigo a Vara da Infância e Juventude.

Os filhos das mulheres agredidas também podem ir para a Casa Abrigo, havendo restrição aos meninos acima de 12 anos, meninas podem ir com qualquer idade. Importante mencionar que, segunda a entrevistada, as mulheres que recorrem ao programa são em sua maioria de classes baixas e possuem grau de escolaridade baixo.

Existe um prazo para a permanência na Casa Abrigo, sendo ele inicialmente de 3 meses. A visita foi feita em 28 de outubro de 2008, data em que haviam 10 mulheres abrigadas. Contudo, tendo em vista a falta de conhecimento pela maioria da população da existência de tal programa, há um aumento na procura principalmente quando há divulgação feita pelos canais de televisão.

São recebidos casos que vão desde ameaças até casos de esfaqueamento, sendo que na maioria deles as vítimas vão efetivamente atrás de ajuda após sofrerem várias agressões, quando vêem reportagens na televisão ou são orientadas por alguma amiga que tenha conhecimento das medidas de proteção às vítimas. A falta de conhecimento das medidas de proteção impede que as vítimas tomem coragem para buscarem ajuda junto à autoridade policial, isso porque, temem a possível falta de recursos para sobreviverem, vez que dependem financeiramente dos agressores.

Por outro lado, foi possível apontar também como causa de dependência das vítimas que, pela experiência adquirida da profissional no trabalho junto à Casa Abrigo, caso fosse feito um levantamento histórico da vida dessas mulheres, seria verificado a falta da figura paterna e o abandono. Dessa forma, elas acreditam que estar junto ao marido é melhor, porque apesar de não fazer bem a elas, fazem bem aos filhos.

Questionada sobre a existência da Lei Maria da Penha, a entrevistada disse que as vítimas sabem que ela existe e acredita na sua eficácia, vez que os agressores estão mais temerosos pelo fato de agora serem efetivamente presos. Porém, há um 
grande problema de decepção das vítimas por acreditarem que chegando a Casa Abrigo seriam rapidamente solucionados os seus problemas, ficando assustadas com a demora.

Entretanto, na Casa Abrigo são desenvolvidos diversos programas, com advogada que trata da separação, guarda dos filhos; com psicólogas que fazem tratamento com as mulheres e seus filhos; com médica ginecologista, clínico geral; com enfermeira; com professoras que dão aula de reforço para as crianças e aula para as mães; com professores de educação física; aulas de artesanato como forma de ganharem dinheiro; cursos de cabeleireiro, culinária. Note-se que as crianças são matriculadas na escola, portanto, elas continuam os estudos durante o prazo de acolhimento.

As vítimas de violência doméstica abrigadas geralmente chegam bastante revoltadas e decididas a se separarem de seus agressores. Contudo, com o passar dos dias, com o contato com a família e com o acompanhamento psicológico elas começam a refletir sobre suas vidas para buscarem soluções mais favoráveis.

Nota-se como grande problema das mulheres agredidas a questão da submissão, sendo perceptível o entendimento predominante de que o homem ainda ocupa papel de superioridade na vida familiar. Dentre as formas de submissão, a sexual é aquela de maior ocorrência apesar de compreenderem que esta também é uma forma de agressão. O fato de não desejarem que seus filhos cresçam sem pai, também se configura como forma de aceitação da agressão.

Como ajuda para a solução dos casos de agressão, por decisão do juiz ou por encaminhamento da Casa Abrigo, os agressores e as vítimas são atendidos nos núcleos de atendimento às famílias e autores de violência doméstica. Dessa forma, constata-se que dentre as mulheres que saem da Casa Abrigo e fazem acompanhamento psicológico, algumas conseguem voltar a viver bem com o marido.

A entrevistada observa que, apesar de perceber um aumento na quantidade de ocorrências, após a entrada em vigor da Lei Maria da Penha, temos que levar em consideração o período analisado. Como já mencionado, observa-se um aumento no número de ocorrências e mulheres abrigadas quando há divulgação dos casos de agressão contra as mulheres e conseqüentemente, há orientação sobre os meios legais destinados a solução do problema.

Dando prosseguimento ao trabalho de pesquisa foi possível entrevistar duas vítimas de violência doméstica, o que será utilizado a título ilustrativo. O nome das entrevistadas será mantido em sigilo. 
Maria*, 23 anos, mãe de uma menina, a qual se encontra com ela na Casa Abrigo, não era casada, mas morava junto com o companheiro agressor. Moravam juntos há 1 ano e 3 meses e durante esse tempo ela foi vítima de várias agressões, não tendo revidado a nenhuma delas. Na última agressão ele a ameaçou, dizendo que a mataria caso não fizesse o que ele estava mandando, trazer determinada coisa para ele. Ela saiu de casa dizendo que buscaria e foi direto para a delegacia. Os policiais a acompanharam para que pudesse buscar suas coisas pessoais e o agressor foi preso. Fazia três dias que ela estava na Casa Abrigo e disse que não pensa em voltar para casa. O grau de escolaridade da vítima é baixo, tendo feito até a $3^{\text {a }}$ série e não realizava nenhuma atividade remunerada, dependendo financeiramente do companheiro, que tem 26 anos e faz bico de pedreiro. Moravam juntos apenas o agressor, a vítima e a filha deles, sendo que nos primeiros cinco meses o relacionamento era perfeito. Depois, ele passou a agredi-la e ofender sua família, porém a vítima ainda tinha esperança de que aquilo era apenas um momento que logo iria passar. Dentro de casa o companheiro a tratava como submissa e não havia diálogo entre eles, vez que somente ele podia falar. A vítima não cresceu em um ambiente violento, nunca tendo presenciado nenhum tipo de agressão na casa de seus pais. Afirmou que apenas se sente segura junto com sua família, a qual vive no Paraná, assim pretende voltar para lá assim que deixar a Casa Abrigo. Apesar de não conhecer a Lei Maria da Penha, resolveu procurar a delegacia por ser o único lugar que poderia lhe ajudar, pois já estava esgotada e sabia que se não procurasse ajuda iria alimentar a raiva dele. Na delegacia da mulher ela foi bem tratada e afirmou que não irá retirar a queixa. Por fim, afirmou que está fazendo acompanhamento psicológico e acredita que na Casa Abrigo é dada atenção ao problema da violência doméstica.

Joana*, 18 anos, não tem filhos e não é casada. Antes de ir para a Casa Abrigo vivia com o companheiro há 2 anos e 6 meses. Eles vieram juntos da Bahia e o relacionamento era ótimo nos primeiros quatro meses. Quando foram morar na casa que ele pagava o aluguel, o companheiro começou a agredi-la e isso continuou por muito tempo e, quando ela ameaçava procurar ajuda ele não se importava, porque achava que, como ela não tinha família, não teria para onde ir se saísse de casa. A violência ia de ameaças a agressões, tanto psicológicas quanto físicas e sexuais. Na última agressão ela revidou e o machucou com um copo e então os vizinhos chamaram a polícia que primeiramente os levou para o hospital. Logo depois foram levados à delegacia e, percebendo que ela estava com medo de contar que o companheiro a agredia, o policial 
explicou que agora existia uma lei para protegê-la, ou seja, a Lei Maria da Penha. O companheiro continuou amedrontando a vítima para que ela não denunciasse as agressões. Ela decidiu falar e foi encaminhada a Casa Abrigo e ele, por sua vez, foi preso. Tem duas semanas que ela está abrigada e se sente muito feliz por terem chamado a polícia e por ter saído de casa. Quando vivia com o companheiro ele tentou proibi-la de estudar e trabalhar, mas ela trabalhava como doméstica e fazia o último ano do $2^{\circ}$ grau à noite. Porém, mesmo trabalhando ainda dependia financeiramente do companheiro, pois o salário que recebia não dava para pagar aluguel e se alimentar e, a situação se agravou porque ele passou a exigir metade do salário dela. O agressor, que tem 26 anos, trabalhava fazendo bico como ajudante de motorista. Enquanto ela não entregasse sua parte do salário a ele, as brigas não paravam, sendo que até o dinheiro que ela estava guardando foi gasto por ele. Os irmãos dele e os vizinhos sempre perguntavam se estava tudo bem entre eles, mas ela achava melhor mentir para não se expor. Isso porque, na presença de outras pessoas ele era ótimo, dentro de casa que a situação se tornava difícil. Assim, ela não tinha coragem de procurar ajuda na delegacia, porque ele a ameaçava de morte e ela ficava preocupada por saber que ele já foi usuário de drogas e não tinha boas amizades. O maior medo que ela sentia era de não ter para onde ir caso deixasse o companheiro, entretanto, ficou bastante surpresa ao receber apoio na delegacia e se sentiu confiante ao tomar conhecimento da Lei Maria da Penha. A vítima não pensa em voltar para a Bahia, porque não tem família, ela pretende arrumar um emprego com a ajuda do pessoal da Casa Abrigo e de outras abrigadas que disseram que vão ajudá-la. Pretende também continuar os estudos e não pensa em se reconciliar com o agressor. Quando questionada se presenciava agressões dentro de casa durante sua infância, a vítima contou que todo companheiro que sua mãe arrumava lhe agredia. Cansada de ver a mãe sendo agredida, Joana resolveu sair de casa aos sete anos, mas decidiu voltar para tentar ajudá-la. Porém, o último companheiro de sua mãe, ao se sentir ameaçado com a separação a matou, deixando Joana órfã. Por fim, afirmou que ao chegar à Casa Abrigo se sentiu sozinha, mas foi acolhida pelas plantonistas e pela coordenadora, hoje ela sente que o pessoal é amigo e se diz confortável e, quanto à queixa não pretende retirá-la. 


\section{CONCLUSÃO}

A história da humanidade é marcada pela subjugação das mulheres na sociedade. Assim explicações naturais eram utilizadas como forma de comprovar que os homens pertenciam à raça mais forte e, portanto, eram superiores.

As mais variadas formas de preconceito existentes na sociedade são conectadas como forma de marginalizar determinados grupos, seja pela classe social, gênero ou raça. Decorre daí o preocupante fenômeno da violência contra a mulher, o qual pode ser classificado como resultado do conflito de gênero ou como violência doméstica, familiar, sexual, psicológica ou física.

A violência doméstica contra a mulher, praticada por alguém que mantenha relação de afetividade com ela, ainda hoje não é vista em sua complexidade, ignorandose na maioria dos casos a gravidade de suas conseqüências.

A sociedade vem gradualmente tomando conhecimento da gravidade do problema da violência doméstica, pois durante muito tempo prevaleceu a presunção de que o ambiente doméstico seria um lugar de harmonia familiar. Tal entendimento vinculado a outros mitos cegaram a sociedade para a gravidade das agressões ocorridas no interior de inúmeros lares supostamente livres de problemas.

A violência inserida na esfera privada, ligada à questão da relação de poder existente na violência baseada no gênero, é agravada pela qualidade do agressor. Dessa forma, não se pode tratar igualmente um agressor desconhecido e um agressor que convive com a vítima, vez que a possibilidade de o mesmo agressor voltar a cometer a violência é bem superior quando se trata de um conhecido.

Por outro lado, não se pode justificar a violência contra a mulher tendo como fator determinante o uso de álcool, de drogas ilícitas ou devido ao ciúme do agressor, uma vez que se sabe que o problema está na forma como a sociedade valoriza o papel masculino nas relações de gênero. O fenômeno é muito complexo para ser explicado tendo por base justificativas como o alcoolismo ou o transtorno psicológico do agressor, pois aqui a violência é exercida especificamente contra a mulher e não a qualquer pessoa.

Com o passar dos anos, as transformações ocorridas na sociedade modificaram a compreensão do que se considerava correto e o que seria ato de violência sujeito à regulação social e punição. Dessa forma, a violência dentro do lar historicamente permaneceu escondida devido a não intervenção do Estado e sociedade, perpetuando a crença de que a mulher nasce para servir ao homem. Conseqüentemente, 
temos o problema sendo acobertado pelo silêncio de suas vítimas, convencidas de que calar-se seria a solução.

Durante muito tempo o papel da mulher restringiu-se ao ambiente familiar, após anos de lutas e reivindicações ficou estabelecido o direito de igualdade entre homens e mulheres, conforme disposto na Constituição de 1988. Ocorre que, mesmo com os direitos constitucionalmente protegidos, a subjugação feminina ultrapassa as barreiras do tempo e, ainda que dissimuladamente, permanece a discriminação.

Nota-se que as delegacias especiais ajudaram na divulgação do problema da violência enfrentada pelas mulheres, formando espaços reservados para a denúncia de seus agressores. Tais delegacias representam a principal política pública de prevenção e combate à violência contra a mulher, porém falham ao não articularem a ação policial com outras áreas capacitadas para acolherem e aconselharem as vítimas como o trabalho de assistentes sociais e psicólogos.

No decorrer do trabalho, menciona-se o problema da revitimização, sendo este relacionado à dependência psicológica que por sua vez se justifica pela inserção secundária das mulheres na sociedade. A repetição da agressão é o ciclo de uma relação doentia que ataca a auto-estima da vítima deixando-a dependente do agressor por razões financeiras ou emocionais. Essa forma de violência se apresenta como uma doença social, tendo o Estado o dever de se comprometer com a ressocialização do agressor, indivíduo educado em uma cultura machista que lhe leva a subjugar o sexo feminino. Esse comportamento modifica o cotidiano das delegacias da mulher, dando a elas um caráter absolutamente próprio, exigindo que elas dêem atenção à família, visando restabelecer as regras essenciais para o convívio entre pessoas ligadas por relações afetivas.

A procura pela justiça se justifica pela incapacidade de por fim à relação agressiva. Dessa forma, a elaboração da Lei Maria da Penha apresentou-se como uma grande conquista de todas as brasileiras. Conquista por criar e estabelecer mecanismos para coibir a violência doméstica contra as mulheres, uma das formas mais graves de violação dos direitos humanos, por reafirmar o que as mulheres brasileiras têm alertado o Estado e a sociedade sobre a importância das políticas públicas que coloquem um fim à violência que tem levado diversas mulheres à morte dentro de seus próprios lares.

A aplicação da Lei de violência contra a mulher aponta novos mecanismos que possibilitam um maior engajamento das mulheres para denunciar e formalizar as agressões ou qualquer outro tipo de violência sofrida por elas. 
A nova Lei já se apresenta como efetiva, ao estabelecer como finalidade a recriminação aos antigos valores que ainda pregam a superioridade masculina e não estabeleciam a violência doméstica de acordo com a real gravidade deste crime. Quando os casos chegavam à justiça, aconselhava-se que o casal se entendesse em nome da paz familiar. Conseqüentemente, a maioria dos casos eram arquivados e se julgados recebiam meras penas, como o pagamento de cestas básicas, deixando implantado o sentimento de impunidade.

Por outro lado, a Lei garante proteção por colocar um fim no comportamento cultural de que as brigas conjugais devem ser resolvidas entre o casal. Agora a violência contra as mulheres configura-se como um problema de ordem pública. Busca também, resolver o problema das denúncias feitas e logo retiradas pelas vítimas, o que causava descrédito junto ao poder judiciário e delegacias. Tais desistências ocorriam pelo medo das ameaças, dependência econômica e emocional, entretanto, para que a denúncia seja retirada hoje é necessário que a vítima manifeste seu desejo perante o Juiz, em uma audiência para esse fim.

Assim, por termos finalizado o trabalho como sendo em sua maioria construído por meio de pesquisa bibliográfica, a comprovação da hipótese ficou parcialmente prejudicada. Afirmar que o aumento das denúncias feitas pelas vítimas de violência doméstica ocorreu, sem se comprovar por meio de estatísticas e número considerável de entrevistas, não é possível.

Porém, podemos afirmar que, de acordo com as pesquisas bibliográficas e de campo, com o advento da nova Lei houve uma transformação pela consolidação dos direitos das mulheres. Um texto de Lei que garante proteção às mulheres que venham a sofrer ataques agressivos é uma grande conquista, porém, necessário se faz um comprometimento do Estado e da sociedade para que a Lei não seja apenas comemorada como um acontecimento histórico e sim como a solução efetiva para o problema da violência doméstica. Não basta apenas uma Lei específica, apesar de caracterizar-se como um grande passo, todos devem se comprometer levando-a para o conhecimento de toda a comunidade.

Conclui-se que, a formulação de uma legislação voltada especificamente para a violência doméstica contra a mulher representa um dos mais importantes passos dados para o combate a este mal. Diante do que foi exposto no presente trabalho, podese inferir que a nova Lei mostra-se eficaz ao abarcar em seu texto formas reais de proteção às vítimas, amparando-as concretamente. 
Restou demonstrado que a Lei Maria da Penha é um instrumento legal de proteção, porém cabe a sociedade e ao Estado colocá-lo em prática. Isso porque, tendo como referência os campos que lidam diariamente com o problema, como a Casa Abrigo e a Delegacia da Mulher, podemos afirmar que a edição de uma Lei sem sua ampla divulgação torna-se letra morta. Não podemos permitir que as vítimas por vezes sejam torturadas até que busquem ajuda, pois caso conhecessem seus direitos não se submeteriam à covardia dos agressores, vez que podem ser protegidas por meio das diversas garantias dispostas na Lei Maria da Penha. Assim, fica o alerta para que ela seja do conhecimento de todos e que seja usada conscientemente pelas verdadeiras vítimas de violência doméstica. 


\section{REFERÊNCIAS}

A Lei Maria da Penha: uma conquista novos desafios. Secretaria de Mulheres da CUTDF. Brasília, 2007.

BROWN, Peter. Corpo e Sociedade. O homem, a mulher e a renúncia sexual no início do cristianismo. Rio de Janeiro: Jorge Zahar Editor, 1988.

CAMPOS, Carmen Hein de; CARVALHO, Salo de. Violência doméstica e Juizados Especiais Criminais análise a partir do feminismo e do garantismo. Disponível em http://www.scielo.br/scielo.php?pid=S0104-026X2006000200005\&script=sci_arttext. Acesso em: 20 de setembro de 2008.

CAVALCANTI, Stela Valéria Soares de Farias. Violência doméstica. Análise da Lei “Maria da Penha”, nº11.340/06. Salvador: Pdivm, 2007.

COSTA, Ana Maria; GUIMARÃES, Maria do Carmo Lessa. Controle Social uma questão de cidadania saúde é assunto para mulheres. Disponível em http://www.redesaude.org.br/Homepage/Cartilhas/Controle\%20Social\%20Uma\%20Que st\%E3o\%20de\%20Cidadania.pdf. Acesso em: 20 de setembro de 2008.

CRISPINO, Nicolau Eládio Bassalo In PEREIRA, Rodrigo da Cunha (coordenador). A Família na Travessia do Milênio. Anais do II Congresso Brasileiro de Direito de Família. 1ed. Belo Horizonte: IBDFAM, 2000.

CRUZ, Madge Porto . A saúde da mulher em situação de violência: o que pensam os gestores e gestoras municipais do Sistema Único de Saúde? Disponível em http://www.mulheres.org.br/violencia/documentos/DissertacaoMadgePIPASCUFPE.pdf . Acesso em: 10 de setembro de 2008.

DAHLBERG, Linda L; KRUG, Etienne G. Violência: um problema global de saúde pública. Disponível em http://www.scielo.br/scielo.php?script=sci_arttext\&pid=S1413$\underline{81232006000500007 \& \operatorname{lng}=p t \& n r m=i s o}$. Acesso em 10 de outubro de 2008. 
DEBERT, Guita Grin; GREGORI, Maria Filomena; PISCITELLI, Adriana. Gênero e distribuição da justiça: as delegacias de defesa da mulher e a construção das diferenças. Unicamp: Coleção Encontros. Pagu/Núcleo de Estudos de Gênero, 2006. DIÁLOGOS sobre violência doméstica e de gênero. Construindo políticas públicas. Programa de Prevenção, Assistência e Combate à Violência Contra a Mulher- Plano Nacional. Secretaria Especial de Políticas para as Mulheres. Governo Federal, 2003.

DIAS, Maria Berenice. Afeto, Ética, Família e o Novo Código Civil Brasileiro. Anais do IV Congresso Brasileiro de Direito de Família. 1ed. Belo Horizonte: Del Rey, 2004.

ESPÍNOLA, Eduardo. A família no direito civil brasileiro. 1ed. Campinas: Bookseller, 2001.

EX parceiro não é enquadrado pela Lei Maria da Penha. Disponível em http://patriciagalvao.tempsite.ws/joomla/index.php?option=com_content\&view=article \&id=1344:ex-parceiro-agressor-nao-e-enquadrado-pela-lei-maria-dapenha\&catid=19:reportagens-artigos-e-outros-textos\&Itemid=6. Acesso em 20 de outubro de 2008.

FACHIN, Luiz Edson. Estabelecimento da Filiação e Paternidade Presumida. 1ed. Porto Alegre: Sergio Antonio Fabris Editor, 1992.

FACHIN, Luiz Edson. A reforma no direito brasileiro: novas notas sobre um velho debate no direito civil. Disponível em: http://www2.uerj.br/ direito/publicacoes/mais_artigos/a_reforma_no_direito.html. Acesso em 22 de março de 2008.

FIUZA, César Augusto de Castro In PEREIRA, Rodrigo da Cunha. A Família na Travessia do Milênio. Anais do II Congresso Brasileiro de Direito de Família. 1ed. Belo Horizonte: IBDFAM, 2000.

FREIRE, Nilcéa. Caso Eloá: o que deu errado? Correio Braziliense (DF) 03/11/08

JORNAL Fêmea. CFEMEA-Centro Feminista de Estudos e Assessoria. Ano X. Nº154. Brasília/DF. Nov-Dez.2007

WALD, Arnoldo. O novo direito de família. 13ed. São Paulo: Saraiva, 2000. 
LEI11.340/06 Use sem restrições! Uma vida sem violência é um direito das mulheres. Campanha 16 dias de ativismo pelo fim da violência contra as mulheres. Agende Ações em Gênero Cidadania e Desenvolvimento.

LISBOA, Roberto Senise. Manual de direito civil. 3ed. São Paulo: Revista dos Tribunais, 2004.

MINAYO, Maria Cecília de Souza. Ciência e Saúde Coletiva. A inclusão da violência na agenda da saúde: trajetória histórica. Disponível em http://www.scielo.br/scielo.php?script=sci_arttext\&pid=S1413-

81232006000500015\&lng=pt\&nrm=iso. Acesso em 10 de outubro de 2008.

MIRANDA, Pontes de. Tratado de Direito Privado. Atualização de Vilson

Rodrigues Alves. 1ed. Campinas: Bookseller, 2000.

MOREIRA, Vera Lúcia Nascimento. Violência doméstica. Disponível em http://www.patriciagalvao.org.br/apc-aa-patriciagalvao/home/noticias.shtml?x=1246. Acesso em: 10 de setembro de 2008.

MOTTA, Maria Antonieta Pisano In PEREIRA, Rodrigo da Cunha (coordenador). A Família na Travessia do Milênio. Anais do II Congresso Brasileiro de Direito de Família. 1ed. Belo Horizonte: IBDFAM, 2000.

NOGUEIRA, Jacqueline Filgueras. A filiação que se constrói: o reconhecimento do afeto como valor jurídico. 1ed. São Paulo: Memória Jurídica, 2001.

PEREIRA, Caio Mário da Silva. Reconhecimento de paternidade e seus efeitos. 5ed. Rio de Janeiro: Forense, 1998.

PEREIRA, Rodrigo da Cunha. A Família na Travessia do Milênio. Anais do II Congresso Brasileiro de Direito de Família. 1ed. Belo Horizonte: IBDFAM, 2000.

PEREIRA, Caio Mário da Silva. Direito Civil - Alguns aspectos da sua evolução. 1ed. Rio de Janeiro: Forense, 2001.

PESQUISA Ibope e Instituto Patrícia Galvão. Dados nacionais sobre a violência contra as mulheres. Disponível em http://patriciagalvao.tempsite.ws/joomla/index.php?option=com_content\&view=article \&id=579:dados-nacionais-sobre-a-violencia-contra-as-mulheres\&catid=7:dados-epesquisas\&Itemid=4. Acesso em: 5 de setembro de 2008. 
PROGRAMA Casa Abrigo. Uma Casa com portas abertas para a proteção de sua vida. CDM-DF.

RIBEIRO, Renato Janine In PEREIRA, Rodrigo da Cunha (coordenador). A Família na Travessia do Milênio. Anais do II Congresso Brasileiro de Direito de Família. 1ed. Belo Horizonte: IBDFAM, 2000.

RIBEIRO, Simone Clós César. As Inovações Constitucionais no Direito de Família. Disponível em: http://jus2.uol.com.br/doutrina/texto.asp?id=3192 Acesso em: 09 de novembro de 2007.

SAFFIOTI, Heleieth I. B; MUÑOZ-VARGAS, Monica. Mulher Brasileira é Assim. Rio de Janeiro: Rosa dos Tempos, 1994.

SARTI, Cynthia Andersen; BARBOSA, Rosana Machin; SUAREZ, Marcelo Mendes. Violência e gênero: vítimas demarcadas. Disponível em http://www.scielo.br/scielo.php?script=sci arttext\&pid=S010373312006000200003\&lng=pt\&nrm=iso Physis: Revista de Saúde Coletiva. Acesso em: 10 de outubro de 2008.

SULLEROT, Evelyne. História e Sociologia da Mulher no Trabalho. Editora Expressão e Cultura, 1970.

SUXBERGER, Antônio Henrique Graciano. Novo tratamento da violência doméstica e familiar contra a mulher: uma visão panorâmica da Lei Maria da Penha. 2006.

TEPEDINO, Gustavo. Temas de direito civil. 1ed. Rio de Janeiro: Renovar, 1999.

TJMG Informativo. A presença feminina na Justiça. BH. Março. 2008. Ano 14. Número 125. Pag. 04 
ANEXOS 


\section{ANEXO I}

Entrevista, semi-estruturada, na Delegacia Especial de Atendimento a Mulher:

1. Por que na maioria dos casos ocorre a revitimização?

2. As DEAMs são discriminadas?

3. A procura nas delegacias ocorre mais por mulheres das camadas populares? Elas vão à delegacia não atrás de uma clareza, nitidez de que há um propósito de punir, mas se reivindica a intervenção de uma autoridade que possa regular as ações domésticas? Inicialmente deposita-se nas DEAMs a expectativa de constituírem-se em uma resposta global no enfrentamento ao problema da violência doméstica?

4. Houve implantação de uma rede de serviços eficazes?

5. A Lei dispõe que haja capacitação permanente das Polícias Civil e Militar quanto às questões de gênero e de raça ou etnia. Isso ocorre?

6. Quais são as providências tomadas quando a vítima procura a delegacia?

7. Quando há risco de vida elas são levadas ao abrigo, antes da ordem judicial?

8. Quando da identificação do agressor pela autoridade policial, deve se juntar sua folha de antecedentes criminais. Geralmente eles já têm passagens pela polícia?

9. As vítimas recebem um formulário para preenchimento, tendo de indicar inclusive, qual medida protetiva desejam? Elas estão aptas para tal resposta?

10. No Distrito Federal já foram criados os Juizados Especiais próprios, visando ao atendimento humanitário?

11. A nova Lei estabelece que só é possível retirar a ocorrência em uma audiência. Isso vale para as variadas formas de violência?

12. As mulheres estão denunciando com maior freqüência? Se sim, é porque estão mais informadas?

13. Qual é o papel do psicólogo dentro da DEAM?

14. Deveriam ser criadas mais DEAMs?

15. Há alguma orientação na DEAM quanto aos programas assistenciais? 


\author{
ANEXO II \\ Entrevista, semi-estruturada, na Casa Abrigo \\ 1. Qual a sua idade? \\ 2. Quem era o agressor? Marido, companheiro, parente. \\ 3. Eram casados? \\ 4. Quanto tempo conviveu com seu companheiro? \\ 5. Há quanto tempo iniciaram os conflitos? \\ 6. A violência era uma rotina? \\ 7. Já registrou outras ocorrências contra o agressor? \\ 8. Já procurou a delegacia apenas para assustar seu marido? \\ 9. Antes de vir para a Casa Abrigo trabalhava? Em que? \\ 10. Dependia financeiramente do companheiro? \\ 11. Se sentia dominada pelo companheiro? Acha normal essa posição para a \\ mulher?
}

12. Tem filhos? Qual a idade deles?

13. Quem morava com vocês?

14. Está fazendo acompanhamento psicológico?

15. Tem interesse em se separar?

16. O agressor utilizou algum instrumento para a agressão?

17. Conhece a Lei Maria da Penha?

18. Foi orientada por um $3^{\circ}$ a procurar a DEAM?

19. Foi bem tratada na DEAM?

20. Você esperava que a autoridade policial corrigisse seu companheiro?

21. Você deseja conseguir meios de sobrevivência para se afastar de seu companheiro?

22. Conhece outras mulheres que tenham sofrido violência, que não estejam na Casa Abrigo?

23. Sabe se elas denunciaram seus companheiros?

24. Quando criança/adolescente sofria agressão por parte de seus pais?

25. Acredita que a nova Lei será eficaz?

26. Teve coragem para denunciar por conhecer a Lei? Por saber que dessa forma estaria amparada? 